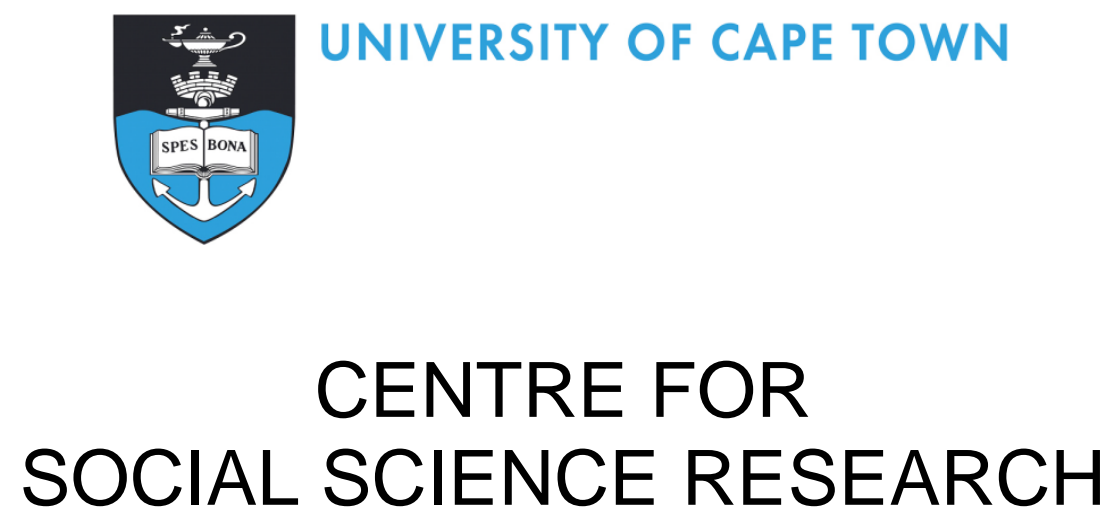

\title{
Development and social policy reform in Uganda: The slow emergence of a social protection agenda (1986-2014)
}

Eduard Grebe and John Bosco Mubiru

CSSR Working Paper No. 353

Legislating and Implementing Welfare Policy Reforms

December 2014
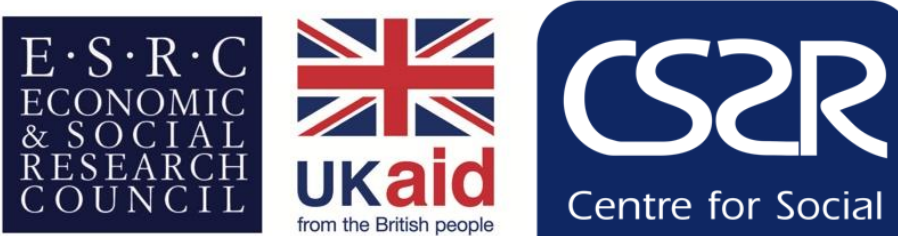

Centre for Social

Science Research 
Published by the Centre for Social Science Research University of Cape Town

2014

http://www.cssr.uct.ac.za

This Working Paper can be downloaded from:

http://cssr.uct.ac.za/pub/wp/353/

ISBN: 978-1-77011-340-4

(C) Centre for Social Science Research, UCT, 2014

(a) Creative Commons Attribution 4.0 International (C.C. by 4.0) licence:

https://creativecommons.org/licenses/by/4.0/

\begin{abstract}
About the authors:
Eduard Grebe is a Research Fellow in Centre for Social Science Research, University of Cape Town, Cape Town, South Africa. Email: eduard.grebe@uct.ac.za.

John Bosco Mubiru is a Senior Researcher for the Development Research and Training, Kampala, Uganda and Research Associate for the Centre for Social Science Research, University of Cape Town, Cape Town, South Africa. Email: mubosc2006@yahoo.com.

\section{Acknowledgements:}

The authors contributed equally to the conceptualisation of, research for and writing of the paper. Interviews with key informants were conducted by Eduard Grebe during early 2014 and the paper was written in late 2014. The joint paper is partly based on two previous conference papers by Grebe on agenda-setting on cash transfers and Mubiru on increasing political support for cash transfers, respectively. The authors would further like to acknowledge the contribution of Prof Jeremy Seekings, who helped conceptualise the paper and provided tremendously useful comments on various drafts. We are grateful for funding for the LIWPR research programme from the UK Department for International Development, through the Economic and Social Research Council, through their Joint Fund for Poverty Alleviation. John Bosco Mubiru was not remunerated for his contribution to this research.
\end{abstract}




\section{Development and social policy reform in Uganda: The slow emergence of a social protection agenda (1986-2014)}

\section{Abstract}

This paper provides a broad overview of the evolution of development and welfare policy — and the politics surrounding - it in Uganda, but focuses primarily on the increasing prominence of social protection, especially cash transfers, on the domestic political agenda. It analyses both how and why the development and social policy agendas almost fully excluded social protection prior to 2002, but then increasingly embraced it, especially since 2006. Non-contributory social assistance in the form of cash transfers have not traditionally played a significant role in Ugandan development and poverty reduction policy, with policymakers tending to focus on economic growth as a source of prosperity (expected to extend to all sections of society), with opponents seeing cash transfers (and social assistance more broadly) as unaffordable and counter-productive 'hand-outs' that create dependence on the state and disincentivise productive work. From the early 2000s donors, sections of the bureaucracy and civil society promoted cash transfers with limited success. But after 2006, systematic promotion of cash transfers started to bear fruit, and from 2010 a largely donor-funded cash transfer pilot scheme known as the Social Assistance Grants for Empowerment (SAGE) programme has been implemented in fourteen districts (with a fifteenth added in 2013). The paper describes the evolution of Ugandan development policy and highlight the political factors that have in the past been obstacles to social protection programmes featuring prominently on the development agenda (including the predominant socio-economic development paradigm, negative elite attitudes, resistance from conservative technocrats and lack of familiarity among key decision-makers) and examine how these have increasingly been overcome by the proponents of social protection. While donors have played a critical role in the promotion of social protection and cash transfers, other actors-including civil society and social development bureaucrats - and macropolitical factors (including electoral competition, changing international development discourse, emerging evidence from other countries, etc.), have also contributed to increased domestic political support. We conclude that the very existence of SAGE and the politics surrounding the pilot indicate a significant change in attitudes among a large proportion of policy-makers, including some historically sceptical 
technocrats, and political leaders, but that resistance is likely to continue from certain quarters and that the future of cash transfers remains uncertain.

\section{Introduction}

Uganda is a low-income country (GNI per capita US $\$ 480^{1}$ in 2012), but has made significant developmental strides over the last decades. In particular it has sustained high levels of economic growth, among the highest in Africa, ${ }^{2}$ and the proportion of the population living in poverty has halved since 1992, although inequality has increased. ${ }^{3}$ (The character of poverty is discussed in more detail in the next section.) The Museveni government has also invested in social services, particularly health and education, and its approach is seen as relatively pro-poor (Melo et al., 2013).

The rest of this paper addresses how development and social policy evolved in Uganda since 1986 (but focusing on the mid-1990s onwards, since it was during this period that poverty became a central policy concern) in an attempt to explain why social protection initially faced strong resistance, but was at first slowly and then increasingly rapidly embraced since 2002. A strong indication of this slow uptake of social protection incorporating cash transfers is the absence of significant social assistance schemes prior to the implementation of Social Assistance Grants for Employment (SAGE) in 2010.

The paper is divided into four major parts. The first provides background by briefly describing the changing character of poverty in Uganda, including substantial decreases in absolute poverty (enabled by strong economic growth), but continuing high levels of vulnerability. The second reviews the history and politics of development policy as it pertains to social protection in the period 1986-2006. During the latter part of this period cash transfers started to appear on the policy agenda, but did not translate into programmatic reform. The third part describes the increase in prominence of social protection and cash transfers on the policy agenda in the period 2006-2013, and the increase in political support,

\footnotetext{
${ }^{1}$ GNI per capita (Atlas method) for 2012 in current US\$ (World Bank, 2014).

${ }^{2}$ Average annual real GDP growth was $6.9 \%$ in $1990-1999$ and $7.2 \%$ in 2000-2009. (Growth rates have since declined.) This compares to $2.1 \%$ and $5.1 \%$ respectively for all low-income countries (World Bank 2014). Also see MFPED (2013), which cites average real GDP growth of $7 \%$ between 2000 and 2012 .

${ }^{3}$ The proportion of the population living beneath the poverty line was 56\% in 1992/93 and 25\% in 2009/2010. This represents an absolute decline of the population in poverty from 10 million to 7.5 million. The proportion of the population classified as non-poor but insecure had, however, increased from $33 \%$ to $43 \%$ over the same period and the Gini coefficient from 0.37 to 0.43 (MFPED, 2012: ix).
} 
particularly since 2006, culminating in the implementation of SAGE from 2010 onwards, which in itself contributed to increasing domestic political support. The fourth part of the paper addresses the question of why political support for social protection and cash transfers have increased, and identifies a range of factors that may help explain this. These include the promotion activities of donors, bureaucrats and civil society, but also the evolving discourse around social protection and how this resonated with sections of the Ugandan political and policy elite. Throughout we aim to identify the political factors that may help explain the initially very low, but later rapidly increasing domestic political support for expanded social protection in the form of cash transfers. In the concluding section we review the most important explanatory factors and identify areas for further research.

Competing policy discourses persist, however, and policy contestation takes place within the context of a global trend of increased interest in and support for social protection. The end of the 'poverty eradication era' (approximately 1995-2002) coincided with a renewed emphasis in the development policy discourse on 'growth and prosperity' (Hickey, 2012) and, somewhat paradoxically, social assistance. These processes are therefore neither simple linear developments nor easy to explain.

The main contribution of the paper is to suggest a number of potentially crucial political factors that may have driven the rise of the social protection agenda in Uganda. These deserve further research, not only to determine which factors have the greatest explanatory power, but also as part of comparative studies of the politics of social protection in East Africa and Sub-Saharan Africa more broadly.

\section{Background: Poverty and vulnerability in Uganda}

Uganda's economic progress is demonstrated by the fact that the proportion of the population living beneath the poverty line reduced from 56.4\% in 1992/93 to $24.5 \%$ in 2009/2010 (MFPED, 2012). This represents an absolute decline of the population living in poverty from 9.9 million to 7.5 million. This data comes from the Integrated Household Survey 1992/93, and the Uganda National Household Surveys 1999/2000-2009/10 (MFPED, 2012). Further reductions were registered in the 2012/13 Uganda National Household Survey (UNHS). However, more than 6.8 million Ugandans still lived in extreme poverty (i.e. unable to meet their basic minimum living requirements) at the time of the 2012/13 UNHS (UBoS, 2013; MFPED, 2014) and an additional $43 \%$ of the population (13 million people) were reported in 2012 as living barely above the poverty line and vulnerable to falling 
into extreme poverty in the event of any shock to their income, such as ill health, disability, death of family member or climate-related risks (MFPED, 2012). The proportion of the population classified as non-poor but insecure increased from $33.4 \%$ to $42.9 \%$ over the period $1992 / 93$ to $2009 / 10$. Income inequality also increased, with the Gini coefficient rising from 0.365 to 0.426 over the same period (MFPED, 2012: ix), but more recently decreasing to 0.395 in 2012/13. There had been notable reductions in income inequality in the central, eastern and western regions while there was an increase in income inequality in the northern region of Uganda (UBoS, 2013).

Poverty reductions in Uganda have generally been attributed to economic growth and development and significant public investment in physical infrastructure as well as some targeted poverty interventions (MFPED, 2014). Nevertheless, many Ugandans still experience hunger, malnutrition and have limited access to health and education services. Poverty rates remains highest in Northern Uganda (44\%) and lowest in the Central Region (4.7\%). At the sub-regional level, 75\% of the people in the North-East (Karamoja) experience income poverty, followed by West Nile (42\%) and the Mid-North (36\%). The high rates of poverty in northern and North-Eastern Uganda is partly explained by the instability and armed conflict that engulfed those regions in the 1980s and 1990s. The incidence of poverty in these regions is much higher than the national average (UBoS, 2013). Rural households are more vulnerable to falling into poverty than urban households. The drivers of vulnerability in Uganda include climatic shocks (drought, irregular rains, or floods), ill health, crop or livestock diseases, and physical insecurityconflict, violence, or theft (MFPED, 2014). According to the Ministry of Gender, Labour and Social Development, Uganda's impressive growth over the past 20 years has been unequal, disproportionally benefiting urban areas and the central and western regions, and benefiting the wealthiest more than the poor (MGLSD, 2012a).

Several categories of people are disproportionately vulnerable to poverty in Uganda. Older persons (variously defined as those over the age of 60 or 65 years - 60 for the purposes of the UNHS - see UBoS, 2013). Households with older persons as members are $32 \%$ more likely to live in poverty than households without older people and over $70 \%$ of such households remain highly vulnerable to falling below the poverty line with even a small shock to income (MGLSD, 2012a). According to the most recent UNHS, the absolute number of older persons has increased from about 1.3 million to 1.6 million over a period of three years (2009/10 - 2012/13), and by 2012/13 constituted about five percent of the population of Uganda. In addition, $75 \%$ of the older persons were heads of households in 2012/13 (UBoS, 2013). 
The vulnerability of older persons and their families is further demonstrated by the fact that the households that slipped into poverty between the 2005/6 and 2009/10 national household surveys were also those that registered the greatest increases in old age dependency ratios (Namuddu et al., 2014). Older persons bear the greatest burden in terms of caring for orphans and vulnerable children (OVCs), with over $60 \%$ of OVCs being cared for by older persons according to the MGLSD's OVC Situation Analysis Report 2009/10 (MGLSD, 2010). It is also reported that over $93 \%$ of older persons in Uganda are not in receipt of a pension or any form of income security (ESP, undated). This leaves this category of the population extremely and disproportionately vulnerable to poverty.

The Social Development Sector Strategic Investment Plan 2011/12-2015/16 (SDIP 2) indicates that in Uganda, widows who are elderly tend to be poorer because they do not control physical and financial resources (MGLSD, 2011b). The majority of older persons live in rural areas where about $85 \%$ of active older persons are engaged in crop farming. The Plan cites the UNHS 2009/10 (UboS, 2010) as indicating that only $7.1 \%$ of older persons currently have access to pensions, of whom $60 \%$ are males. This means that $92.9 \%$ require social protection measures to enable them cope with vulnerability (MGLSD, 2011b). It further reports that existing social protection interventions are not focused on the chronically poor: cash for work programmes (see discussion later) are not appropriate for households with minimal labour capacity while the social insurance institutions which are focused on formal sector workers are not intended to reach the extreme poor, whose livelihoods come from informal and agricultural activities. In addition, anti-poverty programmes supporting income generation activities are largely focused on the moderately poor with work capacity, or on emergency and post-conflict rehabilitation and reconstruction (see discussion on interventions in Northern Uganda later). The majority of Ugandans are not covered by any formal social protection system, and the existing social insurance mechanisms (civil service pensions and National Social Security Fund-also discussed later) only reach those in formal employment.

According to the UNHS 2012/13 (UBoS, 2013), children below the age of 18 years constitute $58 \%$ of the population in Uganda. The MGLSD is mandated to promote social protection of poor and vulnerable children (such as orphans, street children, those under exploitative conditions of labour and those that suffer sexual abuse and other forms of discrimination). According to the Situation Analysis of Child Poverty and Deprivation report (Batana et al., 2014), child poverty has reduced significantly in the last ten years. However, 55\% of children aged 0-4 years live in poverty and $24 \%$ live in extreme poverty. In addition, $38 \%$ of children aged 6 to 17 years live in poverty and $18 \%$ in extreme poverty. The same report indicates that child poverty rates are much higher in Northern Uganda, with the lowest rates in Central and Eastern regions. There are also regional disparities 
with child poverty being much higher in rural areas than urban areas (Batana et al., 2014). ${ }^{4}$ The poverty and vulnerability situation among the children in Uganda is worsened by inadequate staffing and poorly funded national social welfare services (MGLSD, 2011a). The OVC Situational Analysis Report of 2009/10 (MGLSD, 2010) attributes the high level of child vulnerability to general poverty, internal conflicts in some parts of the country and the impact of HIV/AIDS.

Persons with disabilities (PWDs) are a further category of persons that are considered especially vulnerable to poverty. This vulnerability is attributed to their impairment and negative societal attitudes arising from fear, ignorance, superstitions, neglect and lack of awareness (MGLSD, 2009). According to the Poverty, Vulnerability and Inequality Report, households with at least one severely or partially disabled member are more likely to be poor, with poverty rates of $29.7 \%$ compared to $23.5 \%$ for those without such members (Wylde et al., 2012).

The need for non-contributory social assistance to vulnerable groups (most particularly older persons) therefore seems clear-and has in recent years been increasingly recognised among policy-makers and politicians. However, for most of the period since the Museveni/NRM government took power in 1986 welfare policy has been limited in scope, and social protection largely limited to social security for formal sector employees (public sector pensions and the National Social Security Fund for private sector employees). Public assistance to the vulnerable was largely restricted to agricultural livelihoods support and limited welfare interventions (see next section).

From 2010, however, the Ugandan government has been implementing a cash transfer pilot scheme known as the 'Social Assistance Grants for Empowerment' (SAGE) in fourteen districts (in 2013 expanded to a fifteenth). It comprises a social pension available to all persons over 65 years of age (and those over 60 years in Karamoja) known as the Senior Citizen Grant, as well as a povertytargeted grant (Vulnerable Families Grant) aimed at the most vulnerable 15\% of families in the pilot districts. SAGE is the first significant cash transfer programme in Uganda and is being funded primarily by donors (DFID, IrishAid, and UNICEF) and administered by a dedicated secretariat (the Social Protection Secretariat in the MGLSD), which receives substantial technical assistance and capacity-building support from donors. The programme was initiated and promoted by donors, but has been embraced enthusiastically by sections of the Ugandan bureaucratic and political elite while facing scepticism and resistance from others (see Grebe, 2014a). It forms part of the broader 'Expanding Social Protection' programme aimed at 'embedding a social protection system' in

\footnotetext{
${ }^{4}$ The analysis in the report was based on the Uganda Demographic and Health Survey 2011.
} 
Uganda and building domestic political support for social protection and cash transfers in particular. Since the implementation of SAGE, a domestically-funded universal social pension has also emerged prominently on the policy and political agenda, and is being seriously debated in policy and political circles, as well as publicly. It has even become an election issue.

\section{Ugandan development policy (1986-2006)}

\subsection{Stabilisation, growth and state-building after Museveni takes power (1986-1995)}

Given the recent end of the bush war and general state of collapse, the policy focus during the initial years of the Museveni regime was on re-establishing order and security, state-building and economic stabilisation. These were prerequisites of exercising effective governmental authority (and retaining power) as well as of the success of any developmental interventions.

Initially, a lack of consensus about macroeconomic policy (particularly the choice of an open versus a closed economy) resulted in some policy confusion (Kasekende and Atingi-Ego, 2008: 255), but after a number of failed interventionist attempts at stabilisation, a package of structural adjustment reforms was agreed with the IMF in 1987. This resulted in a range of liberal reforms in agricultural and input prices, the exchange rate, and more disciplined fiscal policy. Economic policy reforms were accompanied by institutional reform, including the merger of the Ministry of Finance and the Ministry of Planning and Economic Development to form the Ministry of Finance, Planning and Economic Development (MFPED), and the introduction of annual Medium Term Expenditure Frameworks (MTEFs) covering three financial years and aimed at ensuring improved fiscal discipline through 'hard budget constraints'. Uganda was one of the first developing countries to introduce MTEFs and its system is among the most highly regarded (Whitworth and Williamson, 2011: 16).

There existed some recognition that these reforms were having unintended negative consequences for some categories of poor people. As a result, some efforts were made to ameliorate the impacts, including the Programme for the Alleviation of the Social Costs of Adjustments (PAPSCA), which aimed to provide services in areas where those worst-affected by the reforms were living, as well as targeted credit programmes, such as the Rural Framers Credit Programme and Seed-capital (etandikwa), for groups and individuals with skills but without the capital to initiate investment projects. 
Uganda sustained relatively high levels of economic growth, with average annual GDP growth of 6.9\% between 1990 and 1999 (World Bank, 2014). The Museveni government gained a reputation for good governance, low levels of corruption (although reputation doesn't necessarily reflect reality), and good management of the economy, consequently attracting high levels of foreign aid. ${ }^{5}$ Its policies have been widely described as pro-poor (Mosley, 2012, Melo et al., 2013). Growth and macroeconomic stability created fiscal space for increased investment in human capital development after the mid-1990s whilst donors were at the same time moving towards a focus on poverty eradication (reflected especially in the World Bank and IMF's Poverty Reduction Strategy Papers and Highly Indebted Poor Country debt relief processes referred to below).

For most of the post-colonial period, Uganda's developmental trajectory was largely a continuation of the approach of late colonial British policy, described by Seekings (2013) as 'developing' African economies through 'rather ineffective "developmental states" focused primarily on agricultural development'. In the first decades after Ugandan independence, development policy continued to focus on agricultural development in the countryside (Mamdani, 1976) with what Ferguson (2012) calls 'strategies of restoring and developing peasant agriculture [that] were tightly bound up with fantasies of a communal and caring rural society that had to be restored'. Care for and assistance to the poor therefore continued to be seen as the responsibility of kin and community, best supported by improving rural livelihoods. In contrast to Southern African British colonies (especially the 'settler colonies') no 'poor law' tradition existed in Uganda, and the relatively fertile soil and predictable rainfall obviated the need for regular large-scale food aid and input subsidies on the scale of those provided in countries like Malawi.

Direct public assistance to the poor and vulnerable did not feature prominently in the development discourse of the post-1986 period. Rather, support for agricultural livelihoods (agricultural modernisation) and growth-oriented investment (state investment facilitating private-sector growth - investment in roads and other infrastructure was seen as necessary for the latter, for example) was considered the primary means of addressing poverty and underdevelopment.

\footnotetext{
${ }^{5}$ In recent years, corruption has become more of a concern and in November 2012 the donor community instituted a suspension of aid in response to an audit report detailing serious irregularities and misuse of funds in the Office of the Prime Minister (Cammack and Twinnamatisko, 2013).
} 


\subsection{The 'poverty eradication era' (1995-2002)}

For most of the period since Museveni and his National Resistance Army (NRA) ${ }^{6}$ took power in 1986, Uganda has pursued a market-friendly and growth-oriented development policy (and continues to do so). The mid-1990s to the early/mid2000 s is often referred to as 'the poverty eradication era', when poverty featured centrally in development thinking. During this period the Poverty Eradication Action Plan (PEAP) of 1997 (MFPED, 1997) placed poverty reduction at the core of Ugandan development policy (see below), and the Poverty Reduction Strategy Paper (PRSP) process made poverty reduction strategies a condition of debt relief under the Highly Indebted Poor Country (HIPC) initiative of the World Bank and IMF. The PRSP process replaced structural adjustment programmes in many cases - including Uganda - as the World Bank and IMF's primary agreements with governments on addressing 'development'.

It has been suggested that domestic politics also drove the new focus on poverty, with the campaigns for the Constituent Assembly elections of April 1994 and the Presidential and Parliamentary elections of May and June 1996 regarded as important events. In these elections, it is argued, politicians came face to face with the reality of rural poverty - many people who came for the campaign meetings used the slogan 'although we sleep peacefully we cannot eat peace!' A landmark event occurred in September 1996, when President Museveni mobilised Members of Parliament, donors and government ministers, taking them to the Luwero triangle. The Luwero triangle in central Uganda was the place where Museveni had launched his victorious guerrilla war. The President said the trip was to bring donors and politicians face to face with the state of roads, schools, dispensaries, and the extent of poverty in the countryside (Ssewakiryanga, undated).

But social assistance and 'social safety nets' remained very marginal as potential anti-poverty measures. Some later described the PEAP as 'social developmentfriendly' because it stressed the need for interventions in health, education, water, and sanitation, and emphasised social development as a priority action for reducing poverty and vulnerability (DRT, 2006). During this period, high economic growth rates continued, ${ }^{7}$ creating the fiscal space for increased social expenditure, as mentioned above, but the expenditure was primarily focused on human capital development (investments in health and education, etc.).

\footnotetext{
6 The National Resistance Army would soon after be renamed the National Resistance Movement (NRM), which has remained in power continuously, including after the reintroduction of multiparty parliamentary elections.

${ }^{7}$ Average annual real GDP growth was 6.9\% in 1990-1999 and 7.2\% in 2000-2009. (Growth rates have since declined.) This compares to $2.1 \%$ and $5.1 \%$, respectively, for all low-income countries over the same periods (World Bank, 2014).
} 
Uganda invested substantial resources in social services like health and education (Hickey, 2012), introducing universal primary education in 1997 (Nishimura et al., 2008) and abolishing user fees for health services in public-sector facilities in 2001, with a marked increase in utilisation (Nabyonga et al., 2005). Unfortunately, increased public expenditure did not necessarily result in commensurate improvements in service delivery (Reinikka, 2001) - the quality of education may have declined as enrolments increased (Deininger, 2003; Robichaud et al., 2014), education budgets stagnated in recent years (Robichaud et al., 2014), and out-of-pocket expenditures on health remained high (Orem et al., 2011).

During the 'poverty eradication era' public assistance to the vulnerable remained largely restricted to agricultural advisory services (the National Agricultural Advisory Services, or NAADs), district-level social development services (including OVC programmes that are largely donor-driven, probation, and social welfare services), a small number of 'social safety nets' in the form of school feeding schemes, a district-administered grant to organised disability groups (the Special Grant for Disabled Persons), and a recently-launched Youth Livelihoods Programme for organised youth groups. Reconstruction and recovery programmes have been in place in Northern Uganda since the early 2000s, such as the Northern Uganda Social Action Fund (NUSAF), financed by the World Bank $^{8}$ and the Northern Uganda Agricultural Livelihoods Recovery Programme (ALREP) and Karamoja Livelihoods Programme (KALIP), both financed by the European Union. These have included some social protection elements (like public works, 'cash for work' youth schemes, and Village Savings and Loans Associations), but are mainly restricted to the economically active and aimed at stimulating productive activity (discussed in greater detail later in this paper).

The PEAP of 1997 did, however, signal a significant shift in Ugandan development discourse, as argued above: it placed poverty at the core of development policy. According to Mugambe (2011: 158) it had its roots in both public frustration over the failure of economic growth to significantly reduce poverty (widely aired during the 1996 presidential and parliamentary elections), and international pressure to address poverty more comprehensively (articulated forcefully at a 1995 donor conference in Paris). A National Task Force on Poverty Eradication was assembled under the leadership of the MFPED which led a

\footnotetext{
${ }^{8}$ The World Bank's initial efforts to promote social protection in Uganda started in 2002 via training workshops on social risk management, which influenced DFID's then-Social Development Advisor (discussed later in greater detail). After attending one of the workshops, the Advisor devised a strategy of influencing the Government of Uganda's policy on social protection via establishment of a Social Protection Task Force within the Ministry of Gender, Labour and Social Development (Hickey et al., 2009). More recently the World Bank has started promoting a social protection strategy across the continent (World Bank, 2012).
} 
consultative process involving government, donors and civil society. The final PEAP was adopted by Cabinet in 1997 (MFPED, 1997).

The PEAP was intended to serve as a guide to the formulation of government policy (complemented by specific sector investment plans) and signalled a clear shift towards poverty reduction, rather than economic growth, as the overarching policy goal. However, the 'pillars' and 'priority service delivery areas' articulated in the Plan made clear that livelihoods and income-generating opportunities remained the central mechanism for poverty alleviation. While the Plan did not contemplate any extensive social protection and made no reference to cash transfers, social service delivery (including education and health) featured prominently. The inclusion of Universal Primary Education (UPE) in the Plan followed Museveni's pledge of free primary education during the 1996 Presidential election campaign.

Real efforts were made in the wake of PEAP's adoption to align expenditure to both its specific goals and poverty issues more broadly in the budget process, evident particularly during a review of the Public Investment Plan undertaken in 1998, although many poverty-focused projects were identified but left unfunded (Kakande, 2011:227). However, while poverty reduction had become the primary objective of development policy, the means of achieving this goal remained contested, and social protection had not really entered the development policy agenda. Directly raising living standards through improved social services had gained in prominence, but the PEAP still primarily reflected the 'trickle down' model of poverty reduction as opposed to one founded on direct assistance to the poor.

The PEAP was revised several times, and these revisions featured more extensive civil society participation than the initial drafting (Mugambe, 2011: 161) as well as an attempt to consult the poor through the Participatory Poverty Assessment process and to draw on a stronger evidence base in the form of the Poverty Status Report published in 1999 (MFPED, 1999). The first PEAP revision was recognised by the World Bank and IMF as Uganda's Poverty Reduction Strategy Paper (PRSP) in 2000 - a requirement of debt relief under the Highly Indebted Poor Country (HIPC) initiative - and is now widely seen as a model for PRSPs.

Until the third revision of PEAP in 2004 (described in the next section), even 'social safety nets' received little consideration in poverty reduction and development planning during this period; social assistance largely remained at the margins of development until the mid-2000s. 


\subsection{Agenda-setting on cash transfers and livelihoods programmes in Northern Uganda (2002-2006)}

Social protection was almost entirely absent from the first two PEAPs, but it at least attracted some mentions in the second revision of the PEAP, produced in 2004. It recognised social protection as a cross-cutting issue to help address risks and vulnerabilities and to prevent the poor and vulnerable from sinking into deeper poverty (MFPED, 2004). Hickey et al. (2009: 64) argue that the overall politics of the PEAP process at the time was characterised by strong MFPED resistance to social protection, which viewed it as unaffordable and preferred both the 'productive potential of broad-based investments in human capital via health and education' and a 'broader policy preference to target the "economically active".

\subsubsection{The Northern Uganda Social Action Funds and Labour-Intensive Public Works}

World Bank and European Union reconstruction and recovery programmes in Northern Uganda included some social protection elements (public works, 'cash for work' youth schemes, and Village Savings and Loans Associations), but were mainly targeted at the economically active and aimed at stimulating productive activity. These programmes nevertheless were significant, with large sums expended in the World Bank-financed Northern Uganda Social Action Fund (NUSAF) - which was later renewed-and EU-funded Northern Uganda Agricultural Livelihoods Recovery Programme. The interventions aimed at Northern Uganda - forming part of a broader Northern Uganda Reconstruction Programme (OPM, 2010) - were implemented in the aftermath of decades of disruption caused by conflict, collapsing state infrastructure, and were in part occasioned by the more precarious nature of agricultural livelihoods in this region. They were generally seen (and treated) as exceptional, existing outside broader social protection policy. Golooba-Mutebi and Hickey report:

'Importantly, there was also a strong sense that previous efforts to promote peace, development and reconstruction in northern Uganda had failed and were in need of renewal. It was in this context that NUSAF was announced amidst much official fanfare in 2002 as the main poverty reduction initiative for the north. The state-owned newspaper reported that "The Government has unveiled its strategic master plan on health, security, education, food and other areas of intervention to end the suffering in the insurgency-riddled northern Uganda", and, coining a significant phrase, that "The Government has 
initiated a US $\$ 100 \mathrm{~m}$ project to ensure that the north catches up with the rest of the country in the development process"' (2010: 1222).

The first NUSAF, known as NUSAF I (funded to the tune of $\$ 133 \mathrm{~m}$ ) ran from 2003 to 2009 and NUSAF II, with a budget of $\$ 100 \mathrm{~m}$, started in late 2010 . The first NUSAF was funded primarily through an International Development Association (IDA) credit from the World Bank to the Government of Uganda and became effective in February 2003. Its objective was to empower communities in 18 districts of Northern Uganda by enhancing their capacity to systematically identify, prioritise, and plan for their needs within their own value systems and ultimately, to improve economic livelihoods and social cohesion. NUSAF I had four components: (1) Community Development Initiatives, which provided health, education, transport, water and sanitation infrastructure to communities; (2) Community Reconciliation and Conflict Management, including training and activities to support peace building, traditional systems, and psychosocial programmes; (3) Vulnerable Groups Support, which provided a variety of group based interventions designed to reduce the vulnerability of especially poor and marginalised groups. Interventions included income generating activities, vocational training, life-skills training, cash support to families and food security, among others; and (4) The Youth Opportunities Programme (YOP) which was added to NUSAF in 2005 (see Blattmann et al., 2009.)

NUSAF I did therefore not include a public works component (McCord et al., 2013), but NUSAF II, which started operating in 2010, did. NUSAF II was designed and agreed in 2009 jointly by the Government of Uganda, DFID and the World Bank. The main change from NUSAF I is the major shift in implementation modality, reflecting the challenge identified in a progress report, with the programme now being implemented directly by district authorities, rather than through parallel structures and a separate Management Unit (MU). The second major change was the addition of a public works programme (PWP) component. As a result, in addition to the institutional development component, NUSAF 2 has three, rather than two components targeted at the wider population, namely; (1) household inputs, (2) community infrastructure development using community labour (for example, houses for school teachers), and (3) public works employment and asset creation. NUSAF 2 was designed to be implemented in 40 of the 80 districts in existence in 2009 (which have subsequently increased to 112 ), in what is sometimes known as 'the Greater North'. It is financed by a $\$ 100$ million loan from the World Bank (McCord et al., 2013). These were not the first public works programmes in Uganda. As McCord et al. explain:

'There is a long history of Labour Intensive Public Works (LIPW) in Uganda, with community road maintenance programmes implemented from the 70 s to the early 90 s, after which road maintenance was 
increasingly privatised and mechanised. During the decades of conflict food aid and humanitarian interventions dominated in the north, and little. Public Works activity took place, but during the 2000s multiple PWPs have been implemented in areas of Northern Uganda which were sufficiently peaceful, with agencies such as UNHCR using food-forwork (FFW) approaches to develop the infrastructure required for distribution of relief items, including food. In recent years an increasing number of PWPs have been implemented with the objective either of relief or direct livelihood support, with PWP using food, cash or vouchers (redeemable for agricultural inputs) for work (FFW, CFW and VFW) replacing food aid for returnees; or infrastructure development for livelihoods reconstruction and recovery. However, most PWPs were small-scale and fragmented with considerable diversity of donors and implementing agencies. Currently, NUSAF 2 is the one large scale PWP being implemented in Northern Uganda, and there are three other major donor funded programmes which include some CFW, VFW or FFW elements (KALIP 9 , RALNUC $2^{10}$ and $\mathrm{DAR}^{11}$ ), and a number of other smaller programmes which entail PWPs, including the Local Government Road Maintenance programme which employs communities and adopts labour intensive road construction techniques and small-scale PWP interventions implemented by NGOs' (2013: 5).

\subsection{2 'Social safety nets' enter the policy agenda}

More relevant for our purposes is the history of proposals to extend 'social safety nets' and non-contributory social assistance aimed at reaching the poor and vulnerable. The major proponents of cash transfers in Uganda are social development bureaucrats within the MGLSD, NGOs working specifically with the poor and vulnerable (particularly the rural poor who rely on small-scale and subsistence agriculture), a small number of MFPED bureaucrats, a few politicians and, since the early-2000s, donors like United Kingdom's Department for International Development (DFID). It is notable that the World Bank-now primarily involved as a source of finance for reconstruction programmes in Northern Uganda - made early efforts to promote social protection in Uganda, starting in 2002 by means of training workshops on social risk management, which are reported to have influenced DFID's then-Social Development Advisor. After attending one of the workshops, the Advisor devised a strategy of influencing the Government of Uganda's policy on social protection via

\footnotetext{
${ }^{9}$ Karamoja Livelihoods Programme.

${ }^{10}$ Restoration of Agricultural Livelihoods in Northern Uganda Component.

${ }^{11}$ Development Assistance to Refugee Hosting Areas.
} 
establishment of a Social Protection Task Force within the Ministry of Gender, Labour and Social Development (Hickey et al., 2009). This history of donor promotion of social protection is elaborated in greater detail in Grebe (2014a) and only a few key developments mentioned here.

In 2002, the SPTF - chaired by the MGLSD and including representatives from the MFPED, Office of the Prime Minister, donors (most prominently DFID and the World Bank), and civil society — was established (ESP, 2013a). It identified a wide range of 'micro-initiatives' in existence, but noted that these operated in a policy vacuum and that demand for social protection vastly outstripped supply. It recommended a strengthened regulatory framework and a range of interventions from tax-financed minimum income guarantees to expanded compulsory contributory social security (Devereux et al., 2002). ${ }^{12}$ The history of the SPTF and its transformation into the Social Protection Sub-Committee in 2006 is recounted in Grant (2006) and Grebe (2014a).

The first official government document to extensively treat social protection as a policy response to extreme and chronic poverty, the first Social Development Sector Strategic Investment Plan (SDIP) was also produced in 2002 (MGLSD, 2003). In developing the SDIP cognisance was taken of the areas identified for attention in forthcoming PEAP revisions, especially social protection. In addition, the SDIP focused on processes and mechanisms to improve the policy framework, promote civil society and private sector involvement, increase resources, and, crucially, design and implement effective social protection programmes for the poor and vulnerable. The SDIP indicated that social protection is a multi-sectoral issue that requires action at different levels. In the past, 'social protection' had been mainly associated with 'safety nets' targeted at chronically poor groups such as widows, orphans and people with disabilities. In the SDIP, the concept of social protection was broadened to include areas of risk reduction and risk management. It recognised that for effective risk management social protection had to be 'mainstreamed' at a macro-policy level, within sector approaches as well as through targeted community-level programmes. The SDIP identified three areas for social protection interventions. These were (1) support to people in difficult circumstances; (2) community mobilisation and empowerment; and (3) promotion of employment and productivity.

While even the SDIP largely reflected the prevailing emphasis on livelihoods and improved income-generation opportunities for the poor, it also called for a 'strengthened institutional and regulatory framework for social protection'

\footnotetext{
${ }^{12}$ Interview, James Kabajo, MP (5 February 2014).

${ }^{12}$ Interview, James Kabajo, MP (5 February 2014).

${ }^{12}$ Interview, Isaac Arinaitwe (30 January 2014).
} 
(MGLSD, 2003: 10). It further envisaged specific support and safety nets aimed at 'people in difficult circumstances', including such vulnerable groups as orphans, child labourers, people with disabilities, those affected by HIV and the elderly (MGLSD, 2003: 14). (A second iteration of SDIP-known as SDIP 2would be developed in 2012, in a more conducive political environment. See next section.)

These developments appear to have represented an effort by donors, the MGLSD and civil society to place social protection on the development agenda, but with limited success and in the face of substantial resistance, especially from technocrats in the MFPED. It is reported (for example by Grant, 2006), that DFID's spearheading of the process - and insufficient attention to building political support — contributed to the slow progress (also see Grebe, 2014a).

There was an effort at mainstreaming social protection concerns into the PEAP. In 2002, one donor funded consultancy services to the Ministry of Gender, Labour and Social Development (MGLSD) to help it identify issues of risk and vulnerability. This work resulted in a report on risk and vulnerability in Uganda (Devereux and Sabates-Wheeler, 2002). A second phase was meant to identify social protection measures that might possibly contribute to addressing these issues of risk and vulnerability. As this work was meant to take place at the time of the PEAP Revision, its scope was changed accordingly. The consultants were asked to produce a social protection issues paper (Devereux and Sabates-Wheeler, 2003) to cover selected sectors and to engage with those sectors to see how issues of risk and vulnerability might be best addressed and what concrete social protection measures might be taken. When the sector papers and the draft PEAP were released, the same consultants were asked to assess to what extent social protection concerns were incorporated. The influence of this work on the PEAP revision process was judged as being less than satisfactory because of the absence of support from a strong local constituency, which was instead being led by a marginalised ministry and was too donor-driven (Devereux and Sabates-Wheeler, 2004).

The 'social safety net' measures included in PEAP III (MFPED, 2004) were restricted in scope and for the most part were not envisaged to take the form of cash transfers. Examples included a school feeding programme, a commitment to implementing health insurance schemes, and measures targeted at specific vulnerable groups. However, few of the envisaged measures became policy or budgetary priorities after the publication of the Plan, with the school feeding programme never proceeding beyond a minor pilot, and most of the measures aimed at vulnerable groups contained in SDIP failing to be awarded a 'Certificate of Financial Implication' by MFPED and consequently receiving no budgetary allocations (Hickey et al., 2009: 63-64). 
Civil society voices around this time also started to call for an increased focus on social protection. The first Chronic Poverty Report of 2005 represented one of the earliest efforts by civil society to promote social protection as a core element of the development agenda, arguing that evidence from other low-income countries suggested that social protection measures were both desirable and affordable. It stated that:

'Policy has had relatively little to say about vulnerability ... the time has come to consider rebalancing the effort on modernisation, entrepreneurship and human development with greater emphasis on security and protection' (CPRC Uganda, 2005: 11).

Even donors apart from DFID were not yet showing much interest in social protection (see, for example, ADB et al., 2005). The Ugandan government continued to exhibit a clear preference for the livelihoods-oriented 'social action fund' model in which disbursements are made to groups who exhibit entrepreneurial initiative. Examples include the Special Grant for Persons with Disabilities, which was paid over to districts - approximately USh $30 \mathrm{~m}$ per district (NADC, 2012) - and at that level disbursed to organised groupings of disabled persons, who were encouraged to use the funds to establish incomegenerating schemes like micro-credit associations and small-scale manufacturing operations. The underlying logic appears to have been that the assistance should help vulnerable people become self-sufficient and productive, rather than to directly support income and consumption. Perhaps the most significant example was NUSAF, which funded a large number of livelihoods projects (including agricultural revitalisation, small-scale infrastructure development and public works projects), on the basis of evaluated proposals from NGOs and community groups.

\subsection{Formal social security for a small minority}

Social protection in the form of social security for formal sector employees and retirees has existed for many years in Uganda. Civil servants and other government employees have had access to the state-administered Public Service Pension Scheme (PSPS), originally created in terms of the Pensions Act of 1946, ${ }^{13}$ which in turn succeeded several colonial-era pensions ordinances. Formal social security in Uganda was introduced during the colonial era as a response to the social security needs of the expatriate workers. Msalangi (1998) reports that no 
social assistance scheme similar to those existing in Europe were introduced in the British colonies of Africa (see also Seekings, 2013).

The structure of the current formal social security system reflects its colonial heritage, in part shown by the fact that the existing systems were not altered immediately after independence (Barya, 2009). There is also a Parliamentary Pension Scheme for the staff and Members of Parliament, providing them with pension and gratuity under the 2007 Parliamentary Act. The scheme is contributory in nature where beneficiaries contribute $15 \%$ of their pensionable emoluments while the government contributes $30 \%$ of the monthly pensionable emolument.

The PSPS is a non-contributory and unfunded pension scheme, creating a substantial burden on the fiscus (Platform for Labour Action, 2008: 20). The scheme accounts for over $3 \%$ of the total government budget and in some years it increased to over $6 \%$ when backlogs of arrears were paid to beneficiaries (Huda et al., 2013). The state further administers and funds several pension schemes for members of the armed forces. A National Social Security Fund (NSSF), with compulsory contributions from employees of private sector companies employing five or more employees has been in existence since $1985 .{ }^{14}$ There are also several private or voluntary pension schemes in Uganda. These schemes are managed by employers and public institutions either on their own or through insurance companies. These include MTN Uganda Contributory Provident Fund, Monitor Publications Ltd. Staff Retirement Benefits Scheme, Makerere University Retirement Benefits scheme, Bank of Uganda Staff Retirement Scheme, among others. These schemes were unregulated before the establishment of the Uganda Retirements Benefits Regulatory Authority (URBRA). ${ }^{15}$ The URBRA was established in terms of the URBRA Act (No. 15 of 2011).

The Government of Uganda more recently proposed a Universal National Health Insurance scheme. Under the proposed National Health Insurance Bill, formal sector workers would pay $4 \%$ of their monthly earnings to the insurance scheme, which will be matched by a contribution equivalent to $4 \%$ of their earnings by their employers, while those in the informal sector would be mobilised under a savings scheme, where the same percentage of income would be contributed to health insurance (Mugerwa, 2013). The National Health Insurance Scheme Bill of 2007 has been shelved for over eight years. The scheme was expected to start in the financial year 2012/13 but was halted because of criticisms from major stakeholders, who described it as a further tax burden on employers; these

\footnotetext{
14 The National Social Security Fund Act, Cap 222. See: http://www.ulii.org/ug/legislation/consolidated-act/222.

15 The list of registered schemes can be accessed at: http://www.urbra.go.ug/registeredschemes.html.
} 
criticisms resulted from the fear that the policy might increase the already high costs of doing business in Uganda (Mugerwa, 2013).

These formal social security schemes, which cover fewer than $10 \%$ of the working population (Kidimu, 2013), and the process initiated more recently to reform the social security sector, primarily by liberalising the private pension industry and the proposal for a national health insurance scheme, are not considered in any detail in this paper, since we focus on social assistance to the poor, particularly in the form of cash transfers. But the history of highly restricted formal social security systems may help to explain the lack of interest in social assistance among the elite and middle classes during this period.

\section{Cash transfers attract domestic political support and a pilot scheme is launched (2006- 2013)}

\subsection{Initial moves to implement a cash transfer pilot}

From 2006, the SPTF decided to focus on cash transfers as the primary social protection mechanism it sought to promote (Hickey et al., 2009). A Memorandum of Understanding between DFID and the Government of Uganda to design and pilot a cash transfer scheme was signed in late 2006.

In the latter part of 2006, the Social Protection Task Force was transformed into a Social Protection Sub-Committee of the Social Development Sector Working Group, with representation to the committee being broadened to include a crosssection of civil society organisations, key sector ministries and donor representatives (Lwanga-Ntale, 2008). The Sub-Committee is the main leadership structure within the Government of Uganda on all social protection policy-related issues. The Sub-committee was therefore responsible for leading all social protection policy development, reform and coordination on behalf of the Government of Uganda. At the time of writing, the Sub-Committee membership comprised 40 individuals representing relevant Government of Uganda line Ministries, interested Development Partners, Civil Society Organisations, and Research Institutions. The ministries are represented at the Director and Commissioner levels. The Sub-Committee meets every quarter to discuss issues that the Ministry (latterly in the form of the Social Protection Secretariat) presents to them for guidance and approval. The Sub-committee has been broken down into four thematic groups: Capacity Building, Policy, Programmes, and Communication and Advocacy (ESP, undated). 
The SPTF commissioned external consultants to design a cash transfer pilot scheme (with funding support from DFID), with DRT as the lead partner in the design team (which also included international consultants). It produced a comprehensive proposal, which was accepted and published by the SPTF in June 2007 (MGLSD, 2007). Two of the proposed pilot's primary aims would be to 'demonstrate the desirability and feasibility of such a scheme' and to 'win political support' for cash transfers (MGLSD, 2007: vii). The team clearly sought to base the pilot design on sound evidence, as shown by the series of background papers (including a vulnerability assessment, review of international literature, and simulations/models to inform design choices), and also consulted with civil society and academia in the process.

But it also clearly showed the influence of civil society groupings (particularly certain NGOs and the Ugandan research community) that were concerned primarily with 'chronic poverty' at the time. The terms of reference called for a 'cash transfer pilot scheme to address chronic poverty' (our emphasis) and the design document extensively cited the first Chronic Poverty Report (CPRC Uganda, 2005).

The international NGO HelpAge International worked with the Social Protection Task Force to convene a panel of experts to explore the possibility of incorporating a 'categorical transfer' component in the programme and to support the piloting of a social pension scheme within the framework, should such an option prove feasible. The African Expert Panel on Social Protection in Uganda was held in Kampala in March 2007. Panellists included representatives from the Governments of Uganda, Kenya, Zambia, and the United Kingdom, as well as experts from the South African Economic Policy Research Institute, International Labour Organization, Development Research and Training, Uganda Reach the Aged Association (a national NGO), and HelpAge International (UN, 2008). But a categorical transfer was not included in the final design.

Despite the recognised need to win political support for cash transfers, the SPTF and their consultants appeared to underestimate the opposition even a pilot cash transfer might face. The document revealed little effort to present cash transfers as anything other than a mechanism to directly address poverty (other mechanisms being, for example, estimating the impact on the poverty gap of various options).

The design envisaged targeting beneficiaries in the lowest decile of consumption expenditure and proposed a transfer of USh 18,000 per household (US\$10.58 in June 2007) plus supplementary transfers of USh 2,000 for every child under 18, elderly person (60 and older) and person living with a disability in the household up to a maximum of five supplementary transfers. It proposed six pilot districts 
selected on the basis of a multi-criterion ranking depending on the share of vulnerable people in the district population. It further proposed relatively complex eligibility criteria for individual households and a ranking procedure for selecting from eligible households. The proposed scheme included 'soft conditionality' in an attempt to establish links between the transfer and health, education and nutritional outcomes through 'moral suasion' and 'opt-in incentives' to meet a package of health and schooling commitments (MGLSD, 2007: 15-16). Payments would be made via post offices and parent/teacher associations. The pilot was expected to reach up to 9000 beneficiaries over four years and cost approximately US $\$ 7.7 \mathrm{~m}$ - fully funded by DFID (MGLSD, 2007).

But implementation of the SPTF proposal faced serious resistance from MFPED officials and the then-Minister of Finance, Dr Ezra Suruma, an economist by training, blocked implementation by refusing to issue the required 'certificate of financial implication', without which even donor-funded but governmentadministered expenditure is impossible. The Minister's stated concerns were related to the 'affordability of the project over the long term and its donor-led character' (Hickey et al., 2009: 65). See Grebe (2014a) for a fuller discussion of both this failed proposal and the response of donors (principally DFID) and supportive bureaucrats. This response principally consisted of devising a serious strategy for promoting cash transfers politically and eventually led to the design of a new pilot scheme, which became SAGE (discussed in the next section).

Both financial technocrats and their political principals were aware that once implemented, even a pilot scheme would be difficult to roll back, potentially creating an open-ended financial commitment if donor support evaporated. ${ }^{16}$ But crucially, the SPTF and the designers of the pilot had simply not anticipated the level of resistance the plan would encounter and little groundwork had as yet been done to build awareness of and political support for it.

After the failure of the first proposed cash transfer pilot to win political support, proponents of cash transfers (most significantly DFID and the MGLSD) had no choice but to set out on a well-planned agenda-setting and advocacy exercise (see Grebe, 2014a). It now saw building political support for cash transfers as of central importance and pursued this task vigorously. ${ }^{17}$ A senior DFID official and contracted consultant explained that DFID came to understand that merely offering funds for an initiative would not guarantee its acceptance, particularly when elite attitudes in general were not favourable to social protection and when

\footnotetext{
${ }^{16}$ Interview, Stephen Barrett (13 January 2014).

${ }^{17}$ Interview, Beatrice Okillan (13 January 2014).
} 
financial technocrats and politicians were (rightly) concerned over creating longterm liabilities. ${ }^{18}$

Following the recommendations of the first Chronic Poverty Report (CPRC Uganda, 2005), the Ministry of Gender, Labour and Social Development (MGLSD) had been involved in social protection debates, both at the national and international levels, and became an increasingly vocal supporter of cash transfers. Furthermore, since 2006 the MGLSD, working with the Social Protection Subcommittee-successor to the SPTF-championed efforts to promote a coordinated approach to social protection in Uganda. These efforts and the debates culminated in the design of the Expanding Social Protection (ESP) Programme. Other factors that led to the approval of the SAGE pilot programme include donor and bureaucratic promotion, civil society promotion, and the evolving development policy discourse that emphasised growth, but also increasingly recognised social protection as a potentially feasible and desirable way of assisting those least likely to benefit from economic growth (see Section $5)$. Donor and bureaucratic promotion of cash transfers are treated extensively in Grebe (2014a).

More recently, social protection was strongly endorsed in national development policy through the National Development Plan of 2010. The most recent overarching planning documents are Vision 2040 (GoU, 2013) and the National Development Plan (GoU, 2010). The NDP replaced the PEAPs as the overall development coordinating policy of Uganda. Two features are striking: (1) the inclusion, for the first time, of social protection as a major policy priority in the primary development plan and (2) a renewed focus on growth, employment and private sector development. The latter is indicated by the 'vision' and 'theme' of the document: "a transformed Ugandan society from a peasant to a modern and prosperous country within 30 years" and "growth, employment and socioeconomic transformation for prosperity" (GoU, 2010: i). It has been argued that the NDP signals a turn away from the government's previous focus on poverty eradication to a wider focus on 'prosperity for all' (CPAN, 2013: ix). We view this less as a move away from poverty eradication than as a resurgence of the discourse dominated by efforts at improved livelihood opportunities that privilege the 'economically active poor'. This strand was never absent from the development policy discourse, but had been overshadowed by the poverty eradication discourse during the PEAP era. Somewhat paradoxically, however, this turn coincided with the strong endorsement of social protection. The NDP called for a comprehensive policy on social protection and the implementation of cash transfers (at least in pilot form). The Plan stated, among other things:

\footnotetext{
${ }^{18}$ Interviews, Stephen Barrett and Rachel Waterhouse (13 January 2014).
} 
'640. Social Protection: This entails all public and private interventions that address vulnerabilities associated with being or becoming poor. Social protection is a public investment in human capital that facilitates risk taking endeavours and also enables the poor to prevent, cope with and mitigate risks. These interventions currently include: provision of social assistance to the chronically poor; care for the elderly, Orphans and other Vulnerable Children (OVC); special needs education and training; community based rehabilitation services for PWDs; social security for public sector and formal private sector employees; pension for public sector employees and relief services to disaster victims. In addition, the Government has promoted equal opportunities, operation of social security schemes, labour standards and occupational safety. ...

666. objective 3 - Expand social protection measures to reduce vulnerability and enhance the productivity of the human resource.

Strategy 1: Diversify and provide comprehensive social protection measures for the different categories of the population.

Intervention Description:

i) Formulate a comprehensive social protection policy and strengthen the mechanism for coordination of social protection programmes.

ii) Diversify social security measures to cover more people, those employed in the formal and informal sector as well as the unemployed.

...

vii) Develop and implement social transfer programmes including cash transfer programmes to the elderly, persons with disability and the poorest quartile of the population, and cash for work for the vulnerable youth' (Our emphasis. GoU, 2010).

This is indeed what has since transpired, as described below, with the formulation of a National Social Protection Policy Framework (MGLSD, 2013) within the MGLSD and the design and implementation of the SAGE scheme under the auspices of the broader ESP.

A second iteration of the SDIP, the Social Development Sector Strategic Investment Plan 2011/12-2015/16 (SDIP 2) identified 5 interventions under social protection for vulnerable groups. These were: (1) Provision of social assistance for the chronically vulnerable; (2) Empowerment of vulnerable groups for improved livelihoods; (3) Provision of care and protection; (4) Promotion and Protection of Rights; and (5) Strengthening systems and structures for social protection (MGLSD, 2011b). Under the intervention (1), the SDIP 2 stated that 
the social development sector would provide social assistance in the form of cash transfers to those deemed eligible on the basis of their vulnerability, disability, and old age to meet immediate needs. The sector would encourage informal schemes like individual or family support, community support groups or associations, self-help groups, and micro-insurance. In addition, the sector would advocate for preventive measures to avert poverty and reduce vulnerability and risks. Measures included food for-work schemes in food insecure regions, school feeding programmes for orphans, as well as measures to safeguard health, including drugs for older persons and antiretroviral treatment for persons suffering from AIDS (MGLSD, 2011b).

These policy documents appear to illustrate a genuine emerging commitment to social protection as part of Uganda's development agenda.

\subsection{Designing and winning support for the Social Assistance Grant for Empowerment (SAGE) scheme}

In 2009, DFID and IrishAid contracted Maxwell Stamp to commence the design of the ESP/SAGE programme. In a job posting Maxwell Stamp provided the following background:

'Maxwell Stamp was contracted by DFID and Irish Aid in 2009 to engage Government of Uganda, development partners, CSOs, and communities to redesign cash transfer pilot. The design team worked with the Directorate of Social Protection in the MGLSD and held several consultations in Kampala and initially in two pilot districts (Kyenjojo and Katakwi), followed by a further two districts in Karamoja (Moroto and Nakipiripirit) over the period of July to October 2009. Options papers highlighting key design challenges and issues were presented to stakeholders at a workshop in Munyonyo in August following which, the Programme Memorandum for the Enhancing Social Protection in Uganda (ESPU) Programme was developed for DFID, and further design documentation for Irish Aid' (Maxwell Stamp, 2010).

As part of explicit efforts to secure political support, the proposal was taken directly to Cabinet. In a fortuitous development, Syda Bbumba, who had been Minister of Gender, Labour and Social Development from 2006 to 2008 (i.e. during the period when the first proposal of a pilot cash transfer had failed to win support), had shortly before been appointed Minister of Finance. Her presence on the Cabinet sub-committee established to evaluate the proposal, and the clout 
inherent in her position, together with the fact that a number of senior MFPED officials (including a Minister of State ${ }^{19}$ in the MFPED, Fred Omach) were seen as sympathetic to cash transfers, have been cited as important factors in the proposed pilot winning support in Cabinet and obtaining the necessary clearance from the MFPED. DFID's senior social development advisor, Rachel Waterhouse, described this as the single most important factor in the proposal's success. ${ }^{20}$

As described in the introduction, SAGE is a component of the Expanding Social Protection (ESP) Programme. The purpose of the 5-year ESP programme (20102015), which was approved by Cabinet in 2010, is to embed a national social protection system including social assistance for the poorest and most vulnerable as a core element of Uganda's planning and budgeting processes. The ESP programme adopts a holistic approach to embedding social protection through (1) the development of a national social protection policy and costed strategy; (2) institutional reform and capacity building within the MGLSD and across government as a whole; and (3) engagement with political actors to build understanding and commitment to social protection. These are supported by the SAGE pilot scheme which aims to generate evidence on the impact and feasibility of delivering small but regular and reliable direct income support to poor and vulnerable households (Namuddu et al., 2014). It is intended to directly reduce chronic poverty and improve life chances for the poor and vulnerable through the cash transfer pilot and to embed a national social protection system within Uganda's national planning and budgeting system (Bukuluki and Watson, 2012).

The implementation of the Expanding Social Protection (ESP) Programme started in June 2010. The programme is led by the Ministry of Gender, Labour and Social Development (MGLSD) and supported financially by DFID, IrishAid, and receives technical support from UNICEF. The Government of Uganda is also supporting the programme with in-kind support in terms of personnel, office space, etc., to the value of USh 6 billion over the 5 years (ESP, 2013a). The donor funding originally committed ends in February 2015, but a December 2014 newspaper article quoted the SP Secretariat's Advocacy Advisor as saying "Development Partners have committed another USh 250 billion for Uganda's Expanded Social Protection Programme over the next five years starting in the 2015/16 financial year" (Namutebi, 2014).

\footnotetext{
${ }^{19}$ In Uganda, where terminology often mirrors the British system, Ministers of State are essentially deputy or junior ministers-i.e. they form part of the political leadership of the Ministry, while the administrative heads of Ministries managing the civil servants are known as Permanent Secretaries.

${ }^{20}$ Interview, Rachel Waterhouse (13 January 2014).
} 
SAGE itself is a cash transfer scheme specifically targeted at labour-constrained individuals and households (people with increased vulnerability to poverty due to reduced ability in productive activity). SAGE currently comprises two mechanisms: (1) the Senior Citizen Grant (SCG) that is paid to older persons aged 65 years of age and above (but 60 years in the case of the Karamoja region) and (2) the Vulnerable Family Grant (VFG) paid out to households with low labour capacity owing to age, physical disability, etc., and high dependency ratios. The SAGE initially covered 14 districts ${ }^{21}$ across the four country sub-regions, chosen according to an index based on share of specific demographic groups (children, the elderly, OVCs) as well as on health and education criteria. A fifteenth district (Yumbe) was added in 2013 at the direction of President Museveni and funded by the Government of Uganda, reportedly following a meeting between the President and the district's leadership. A mix of socio-demographic and infrastructure proxy indicators ${ }^{22}$ based on the 2002 Uganda Population and Housing Census was used (OPM, EPRC and Neema, 2013). The probability of a pilot district being included in the SAGE pilot programme was dependent on the score index after summing up of all the proxies in a district.

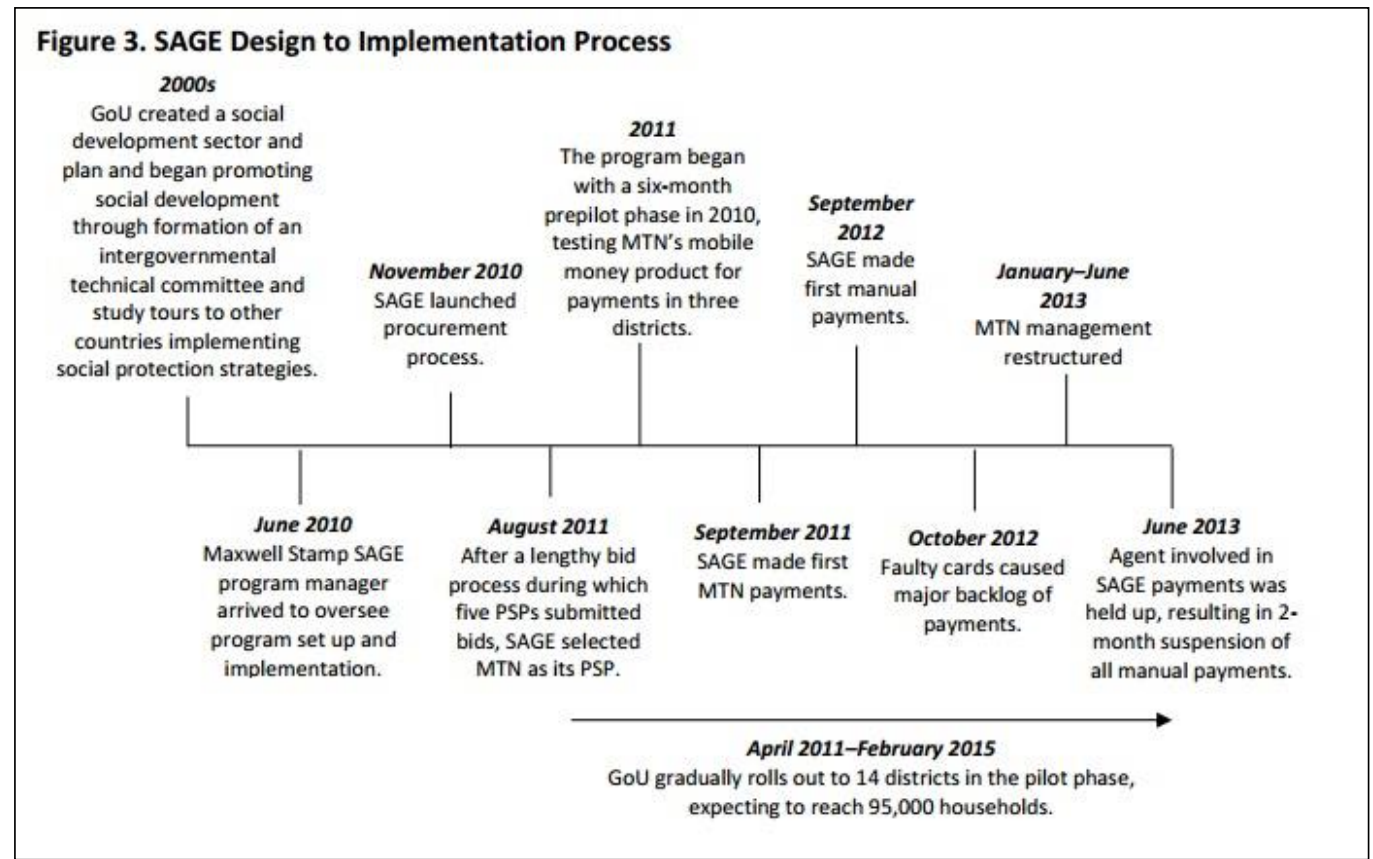

Source: Zimmerman and Bohling (2013)

\section{Figure 1: The SAGE Design and Implementation Process}

\footnotetext{
21 The 14 districts are Apac, Kaberamaido, Katakwi, Kiboga, Nebbi, Kyenjojo, Moroto, Nakapiripirit, Amudat, Kyegagwe, kyankwanzi, Zombo, Napak, and Kole.

22 The proxy indicators were: share of children in the entire population, share of the elderly persons in the entire population, share of orphans and vulnerable children in the child population, share of risky births, proportion of households living more than $5 \mathrm{~km}$ from health facilities, and share of children (6-12 years) not attending school
} 
A total of 108,135 beneficiaries had been enrolled by late 2014 with over $80 \%$ of the programme beneficiaries enrolled in the SCG component. In total, the programme had benefited 550,000 people (Kasaija, 2014). Beneficiaries of both SCG and VFG receive USh 50,000 (approximately US\$20) every two months and over USh 50 billion had been disbursed through the electronic delivery mechanism (MTN Mobile Money) by September 2014 (ESP, 2014). According to Namuddu et al. (2014), the Vulnerable Family Grant component of the SAGE pilot was scaled back in 2013 as a result of strong negative responses to the targeting mechanism from beneficiary communities and local leaders, as well as the higher than expected implementation costs associated with data collection for targeting.

After a corruption scandal following an audit report that uncovered serious irregularities and misuse of funds in the Office of the Prime Minister (OPM), financial arrangements for SAGE were changed. Until that time operational costs for SAGE were paid through MGLSD bank accounts and the responsible Community Development Officer (CDO) at district level. Since then, SAGE payments flow only through bank accounts controlled by Maxwell Stamp Plc.contracted staff. At district level, staff formerly hired by district administrations and financed by the programme, are now employed and managed directly by MSP (Cammack and Twinnamatisko, 2013).

In 2011, the Ministry of Gender, Labour and Social Development (MGLSD) signed a Memorandum of Understanding with the Local Governments to prepare for the implementation of the Social Assistance Grant for Empowerment (SAGE). The MOUs specify the roles and expectations of the various stakeholders in SAGE implementation. They also streamline SAGE operations within the local government structures. The signing of MOUs represented the first step of collaboration with the Ministry of Local Governments and Expanding Social Protection (ESP) Programme (ESP, 2011).

As mentioned earlier, this resurgence of the 'prosperity agenda' (reflected in the NDP and Vision 2040) coincided with the rise in prominence of social protection in general and cash transfers in particular. The latter has won strong backing within sections of the government - particularly the MGLSD — and from donors and civil society. It is important to note that social protection and poverty alleviation policy is rather fragmented in Uganda, with various (usually regional) development programmes including social protection components, varying from public works and 'cash for work' or 'voucher for work' schemes to in-kind transfers. There is limited coordination between these schemes (their design and specific mechanisms often driven by the preferences of particular donors), funding streams operating outside the mainstream budget and implemented by teams segregated from mainstream government structures (usually including 
donor-nominated technical advisors and situated outside the relevant line ministries, such as in the Office of the Prime Minister).

But attitudes have undeniable changed, as reflected in the change of heart of the Minister of Finance that blocked the first proposed pilot-Dr. Ezra Suruma. Recently, as Senior Presidential Advisor on Economic Affairs, he has expressed support for the SAGE grant. During a national dialogue hosted by ESP and the Economic Policy Research Centre, he said in his statement:

'Allow me to use this opportunity to support the establishment of a comprehensive national program for the assistance of people who are unable to earn an income. These include those Ugandans who at some point in their lives find themselves too young, too old or too disabled to look after themselves. I want to appeal to all Ugandans to recognize, accept and support a national program for the assistance of fellow Ugandans who at some point in their lives find themselves unable to earn an income that can afford them a standard of living that is considered worthy of a human being. Since we became independent, we have seen catastrophic fluctuations in political and economic stability. Fortunately, the last 25 years have recorded more economic growth and more political stability than the first 25 years of independent Uganda. As we grapple with the issues of economic growth and the distribution of that growth among Ugandans, we must also grapple with the problem of those in our society who cannot cope with the demands of earning an income' (ESP, 2012).

\section{The politics of cash transfers in Uganda: from resistance to support}

Despite the extensive agenda-setting efforts and vigorous promotion of social protection and cash transfers (some already described, but also see below and Grebe, 2014a), the approval and largely on-schedule implementation of SAGE represents a considerable achievement in overcoming widespread scepticism and opposition. Uganda was slower than many similar low-income countries (notably their neighbour Kenya) to embrace cash transfers.

As we have implicitly and explicitly argued throughout this paper, domestic politics is a key determinant of policy and programme responses to poverty in Uganda. This is in part demonstrated by the evolution of development policy described in the earlier section on development policy in Uganda. Politics plays out among domestic political actors, in domestic political institutions, and at the 
global level - especially in state-donor relations and in the impact of global policy discourses and evidence from countries that have implemented cash transfer schemes (most prominently Brazil, but also other African countries).

In the early 2000s, politics represented a serious obstacle to the implementation of social protection interventions in Uganda, particularly cash transfers. However, this started to change through the agenda-setting and advocacy efforts of donors and bureaucrats (see Grebe, 2014a). The transformation became especially clear after 2006, when domestic political support for social protection became significantly more pronounced. The failure to invest in social protection programmes in the past can be attributed to a set of political factors. These political factors shaped the context in which decision-making on assistance for the poorest took place, and if (as well as which) pro-poor policies would be adopted. Some of the most important political factors that impeded the earlier uptake of social protection and cash transfers are described below.

\subsection{Political impediments to social protection and cash transfers prior to 2006}

\subsubsection{The predominant socio-economic paradigm (economic ideology)}

As was made clear earlier, the predominant view of development was based on an economic growth-centric model, especially among MFPED economists and technocrats, and apparently also within the Museveni regime's 'insiders'. This agenda was mostly centred on maintenance of macro-economic stability (with emphasis being on low inflation, fiscal responsibility, and an open economy), attracting direct foreign investment; investment in infrastructure (especially roads); and promotion of micro-credit and demand-driven agricultural expansion, emphasising higher value-added agricultural production and development of export-oriented and cash-crop driven commercial and smallholder agriculture.

This growth agenda excluded a large proportion of the poorest Ugandans from development programmes (Lwanga-Ntale, 2008). Economists in the main believed that economic growth would reduce poverty and that the chronically poor were a residual group who, at most, needed temporary and specialised welfare programmes (essentially a version of the 1980s 'trickle down' model or so-called 'Washington Consensus'). Furthermore, politicians faced incentives to favour policies aimed at short-term gains. A key informant in the Ministry of Finance, Planning and Economic Development was quoted as having said that: 
'economics is politics and politics is not long term. Politics only has 5 years to deliver and therefore politicians are looking to make clear impacts and dealing with deeper poverty is perceived as less likely to show impacts quickly enough. If assistance is not likely to raise targeted beneficiaries above the poverty line quickly then the political benefits of prioritising these actions are not apparent' (Grant, 2006: 19).

This predominance of an economic growth agenda inhibited the allocation of resources aimed at assisting marginalised and vulnerable groups.

In the second Chronic Poverty Report (CPAN, 2013), the slow embrace of social protection was blamed on a 'political lethargy' around social protection, which it attributed to:

'1) the dominant economic paradigm, which sees [social protection] as a cost, rather than an investment; 2) elite attitudes that blame the poor for their poverty and expect them to address it through behaviour change, that do not have confidence in government's ability to run poverty-reducing programmes and that assert that social protection is unaffordable in Uganda; and 3) the weak administrative and institutional framework' (CPAN, 2013: $x$ ).

These same factors were cited by informants involved in the promotion of social protection in explaining the need to continue building political support. Informants were nearly unanimous in arguing that the Ugandan political and technocratic elites (outside the narrow social development circle) were slow to embrace social protection. But as described below, these attitudes began to change, especially after 2006.

\subsubsection{Negative elite attitudes}

Information from key informants and the limited existing literature (for example, CPRC Uganda, 2005; Grant, 2006) suggests that many members of the political and economic elites in Uganda, in addition to having a relatively homogeneous perspective on poverty, also tend to have negative views about social assistance programmes for the poorest. These included concerns about adverse incentives on the poor (such as disincentivising work), the misuse of 'handouts', 'dependency' among the poor, and over the affordability of such programmes. ${ }^{23}$ Elite members

\footnotetext{
${ }^{23}$ Key informants interviewed for this research were almost unanimous in attributing the slow acceptance of cash transfers to negative attitudes such as those described among the political, policy and economic elites. See also Grebe (2014a).
} 
are apparently quick to apportion blame to the poor, in particular citing laziness, lack of innovation and poor attitudes towards work (Lwanga-Ntale, 2008). Social protection has also been described as a donor or western-driven agenda, unaffordable for Uganda.

Two of the strongest examples of opposition to social assistance were (1) when the Minister of Finance blocked the implementation of the first proposed cash transfer pilot over 'sustainability' concerns (indicating negative attitudes among the political elite) and (2) later, when the Government of Uganda announced the plan for introducing the SAGE cash transfer pilot scheme, public opposition from members of the economic elite and sections of the technocracy (Lwanga-Ntale, 2008). Another informant from the MFPED told Grant (2006) that many influential people were not sensitive to poverty issues, and would argue for different priorities - illustrated by this quote "the country is not only about vulnerable poor people; what about protecting those that have come out of poverty; no free cash to reward people for being poor; growth is key, everything else is secondary" (quoted in Grant, 2006). Our informants were significantly less likely to express these kinds of views in 2014.

Furthermore, members of the elites held a belief that anti-poverty national programmes have predominately failed in Uganda, even though some would argue that moderate progress had been achieved on poverty reduction. The lack of faith in government action on poverty further contributed towards pushing the social protection agenda down the list of priorities (Lwanga-Ntale, 2008). Many informants interviewed for this research recalled that objections were frequently raised that beneficiaries would use cash to purchase alcohol or other nonessentials and that grants would act as disincentives to work and would promote laziness and withdrawal from the workforce. An opinion survey on knowledge, attitudes and practices on poverty, vulnerability, social protection, and cash transfers in seven districts, including Kampala, found that $13 \%$ of respondents by 2011 still felt that cash transfers would result in beneficiaries becoming 'lazy' (Synovate, 2011). Evidence gathered in the course of the fieldwork for this study supports these conclusions on continued resistance. ${ }^{24}$ Systematic evidence on elite attitudes is lacking, but appear to have changed significantly over the last decade.

\footnotetext{
${ }^{24}$ A workers' representative in Parliament, for example, expressed support for and pride in the Senior Citizen Grant, but strongly opposed any cash transfers to other categories of the poor and vulnerable "because this would create dependency on the state" (interview, Rwakajara Arinaitwe, MP, 15 January 2014) and several other politicians expressed similar concerns over cash grants to the non-aged. A further telling anecdote recounted by a knowledgeable informant was that the Deputy Prime Minister made comments at the formal launch of SAGE entirely inimical to the spirit of the programme, including the comment that 'the only solution to poverty is hard work and not government hand-outs' (or words to that effect). (The informant asked for this account not to be attributed.)
} 


\subsubsection{Lack of familiarity with social protection and mixed signals from donors}

A genuine lack of knowledge on social assistance programmes and cash transfers in particular presented an obstacle to both political support for and the implementation of cash transfer schemes.

A significant number of informants interviewed for this research indicated that rising awareness of social protection - and the evidence on its affordability and impacts in low income countries - contributed substantially to changing attitudes. There was limited knowledge on what social protection is, its benefits and how it is implemented, in addition to the lack of a policy framework to guide the implementation of programmes (Onapa, 2010). ${ }^{25}$ Furthermore, there existed a feeling that donors influencing the social protection agenda in Uganda (mainly DFID and World Bank) were giving mixed signals about social protection. The World Bank was guided by their social risk management (SRM) framework whereas DFID was guided by vulnerability and poverty frameworks (Grant, 2006). These mixed signals probably presented an impediment to generating enthusiasm and political support for initiating any pilots as well more general development of the social protection agenda in Uganda.

\subsubsection{Intra-governmental institutional politics}

Rivalry, varying ideological frames and lack of communication, especially between the Ministry of Finance, Planning and Economic Development (MFPED) and Ministry of Gender, Labour and Social Development (MGLSD), further acted as an impediment to the emergence of social protection on the development policy agenda. A point of contention was which ministry should take the lead on social protection. The MFPED was the more powerful institution (as is usually the case, given that it is responsible for resource allocation), while MGLSD had the official mandate to spearhead social development in the country. The biggest dispute between the two institutions centred on the former accusing the latter of having limited financial and technical capacity to implement social protection programmes (Onapa, 2010). There were concerns from stakeholders in the MFPED that the MGLSD was too weak to cope with the coordination role in social protection. Informants from the MFPED, referred to in Grant (2006), argued that the responsibility had to lie within an institution with real power such as the MFPED, the Office of Prime Minister or the President's Office, if social protection was to be taken seriously in Uganda. This brought about debates as

${ }^{25}$ Onapa made a similar point when interviewed for this research. Interview, Paul Onapa (20 January 2014). 
other stakeholders suggested building on the efforts of the MGLSD, and work with it rather than against it (Grant, 2006). This was worsened by the lack of a common understanding on social protection by the different ministers as exacerbated by the lack of a common understanding of social protection among various ministries (Grant, 2006). Hickey et al. further state that:

'The power relations at the centre of official policy processes are heavily skewed in favour of the powerful Ministry of Finance, whereas the social welfare ministry with responsibility for addressing vulnerability is relatively marginal and lacks significant administrative capacity' (2009: 19).

The politics of Social Protection in Uganda has largely revolved around financing and affordability of the schemes. Some politicians have always argued that financing social protection programmes from domestic resources will lead to redirecting funds from other areas of national importance or require substantial improvements in revenue collection. These politicians believe that for a developing economy like Uganda that is still struggling to reach adequate levels of tax revenue collection, financing social protection programmes would be extremely challenging (Lwanga-Ntale, 2008). In a scoping report commissioned by the SPTF early in its existence, Devereux, Lwanga-Ntale and Sabates-Wheeler (2002: 7-8) state:

'...there is a tendency to dismiss social protection interventions as 'welfarist' or 'charity', as though these programmes simply consume scarce public resources and are therefore 'unaffordable' in poor countries like Uganda. This is not our view. Instead, we believe that well designed and targeted social protection interventions can contribute both directly and indirectly to Uganda's poverty reduction goals, and to the objectives of the Poverty Eradication Action Plan (PEAP).'

However, it appears clear that in recent years, there has been much greater support for social protection programmes. Below we will present evidence to this effect and explore in greater detail the factors that may have helped change the perceptions and attitudes of the stakeholders mentioned above and engendered greater domestic political support. 


\subsection{Why has political support for social protection in general and cash transfers in particular increased since 2006?}

Political support for cash transfers has undeniable risen substantially in Uganda, especially since 2006 . This confirmed by most of our key informants and is also evident from the evolution of policy, including the implementation of SAGE.

Despite the fact that the government of Uganda has not been able to fully honour its counterpart financing obligations as per the Memorandum of Understanding signed with the Development Partners, the government has been able to allocate some funds for the SAGE programme. For example, in the financial year 2011/12, only USh 30 million of the USh $125 \mathrm{~m}$ committed was released. In the financial year 2012/13, the Ministry of Finance allocated only USh 39.5 million. But in the financial year 2013/14 the Ministry of Finance allocated a total of USh 2 billion to the SAGE programme (ESP, 2013b). It has been revealed that the donors have expressed commitment to continue funding for the fourteen SAGE pilot districts and the rollout of core delivery systems across the country beyond 2015, although this will be dependent on the government's commitment to provide counterpart funding during the pilot phase and extending the coverage of the senior citizen grant to more districts (ESP, 2013c). We can therefore conclude that fiscal commitments are starting to match the apparent rise in political commitment to cash transfers in Uganda.

Table 1: Original commitment from GoU to financing SAGE

\begin{tabular}{|c|c|c|c|}
\hline $\mathbf{2 0 1 1}$ & $\mathbf{2 0 1 2}$ & $\mathbf{2 0 1 3}$ & $\mathbf{2 0 1 4}$ \\
\hline$£ 20,030$ & $£ 143,000$ & $£ 540,800$ & $£ 1,388,700$ \\
\hline
\end{tabular}

Source: SAGE MoU, cited in Cammack and Twinamatsiko (2013).

The rest of this section will discuss the factors that we identify as having contributed to rising political support for cash transfers.

\subsubsection{Donor and bureaucratic advocacy}

Grebe (2014a) argues that donors, primarily DFID, promoted, but initially failed to secure sufficient domestic political support for cash transfers to progress beyond 'getting them on the agenda'. From the early 2000s, donors managed to team up with supportive social development bureaucrats as advocates of social protection policy reform and cash transfers. This bureaucratic 'buy-in' was an 
essential contributor to the increasing centrality of cash transfers in the development agenda and securing political support for the eventual implementation of a substantial cash transfer pilot scheme. Grebe further argues that the approval and relatively successful implementation of the SAGE pilot, and the fact that a national tax-funded non-contributory pension was firmly on the political agenda by 2013, reflected not only donor influence, but - crucially - also the success of social development bureaucrats in constructing a supportive coalition comprising sections of the bureaucracy (including some finance and planning technocrats), civil society organisations, and political leaders in the legislature and executive.

It is undeniable that donor preferences have been a substantial factor in the development of social protection policy in Uganda. DFID was the primary proponent of cash transfers among the 'development partners', while the World Bank and European Union supported substantial development programmes in Northern Uganda (described earlier) that included some social protection measures.

The World Bank was, at the time of this research, conducting a social protection sector review and was expected to back cash transfers, although it was perceived as being 'late to the party' and not necessarily having much to offer. Some respondents worried that it would impose its preference for conditional cash transfers, potentially upsetting the finely crafted coalition in favour of social pensions. UNICEF had a strong preference for child-targeted grants, but strategically supported SAGE in the hope that the wide acceptance of the SCG would help create the political space for other categorically-targeted cash transfers in future. A grant targeting orphans and vulnerable children was not seen as politically feasible in the near future. ${ }^{26}$

Donor influence was further evident in development policy-making at the national level, where donors have been closely integrated within the national policy processes. Donors have shaped the politics of social protection in Uganda through both their financial leverage and agenda-setting powers. As described earlier, DFID was a driving force behind the Social Protection Task Force (SPTF): DFID funded and exerted substantial influence over the design of SAGE, it funded study trips aimed at changing attitudes among policy-makers. Donors have also supported studies and conferences to provide evidence on the need for social protection. Most importantly, ESP and SAGE are primarily donor-funded.

\footnotetext{
${ }^{26}$ Interviews, Wilbroad Ngambi and David Stewart (31/01/2014).
} 


\subsubsection{Civil society and domestic political advocacy}

CSOs in Uganda have played a significant role in pressurising the government to take up social protection programmes to target the different categories of poor and vulnerable persons in the country. It should be noted, however, that political space for civil society to influence policy in Uganda is constrained by a relatively repressive state (see Grebe, 2014b), and that at least one knowledgeable informant (DFID's Social Protection Advisor) has described civil society as a relatively weak force in social protection policy-making. ${ }^{27}$ CSOs have nevertheless expended significant efforts on lobbying, campaigns and engagement with different stakeholders (including politicians) and have received substantial donor support to do so (see Grebe, 2014a). They may have exerted substantial influence on the policy agenda through these efforts, but probably not through direct political activism.

CSOs such as Development Research and Training (DRT) implemented various approaches including 'co-option'. Key officials both in the MFPED and the MGLSD were identified as focal persons and continuously engaged not only to promote DRT's agenda on chronic poverty and social protection, but also to act as channels to engage their political leadership within the ministries on the benefits of addressing chronic poverty through social protection. Furthermore, DRT identified the 'movers and shakers' of policy-making such as the permanent secretary of the MFPED. Through these engagements, DRT was able to create an interface with the key stakeholders, an approach that helped diffuse the tensions resulting from the contentious politics of lobbying and exerting pressure (Onapa, 2010).

A senior civil society figure argued that government and civil society have a much more productive relationship in this area of policy than in most,${ }^{28}$ but the objective evidence that civil society lobbying has had a decisive impact is limited. DFID considers these organisations an important ally, but their social development advisor in Uganda described civil society activities on social protection as 'quite weak'. ${ }^{29}$ It is also notable that the civil society organisations active on social protection are almost exclusively elite-based and there is little to no popular political mobilisation in demand of cash transfers or other forms of social protection.

CSOs have been very active on a number of committees and platforms where they have been able to advocate and lobby for social protection programmes. The

\footnotetext{
${ }^{27}$ Interview, Rachel Waterhouse (13 January 2014).

${ }^{28}$ Interview, Alfred Nuamanya Buhitsya (30 January 2014).

${ }^{29}$ Interview, Rachel Waterhouse (13 January 2014).
} 
participation of the CSOs on social protection committees dates back to the SPTF's foundation in 2002. As described earlier, the SPTF was later transformed into a Social Protection Sub-Committee of the Social Development Sector Working Group with representation of CSOs, key ministries, research institutions, and donor representatives (Lwanga-Ntale, 2008). This sub-committee is the main leadership structure within the Government of Uganda on all social protection policy-related issues and is responsible for initiating and leading on all social protection policy development, reform and coordination on behalf of the Government of Uganda. The SPTF's efforts in influencing social protection were first evident during the revision of the Poverty Eradication Action Plan (PEAP) in 2003-04, where it made proposals for strengthening the social capital of the poor and enhancing social inclusion of vulnerable groups in the country's mainstream development process. It is through this committee that CSOs have been most influential in creating greater awareness of and lobbying for social protection initiatives in the Uganda.

The participation of the CSOs may have contributed to the integration of social protection in the $5^{\text {th }}$ pillar of the third PEAP of 2004. Civil Society also participated in the development of the NDP, and produced a joint position paper titled Civil Society Input Into PEAP Revision and The Development of The 5-Year National Development Plan (2008-2012) - Social Protection for Uganda's Most Vulnerable And Chronically Poor: Issues, Challenges and Options in January 2008. This may have contributed to the prominence of social protection in the NDP.

Furthermore, there are also administrative structures within the Expanding Social Protection (ESP) programme such as the Steering Committee headed by the Permanent Secretary of the MGLSD, with representation from the MFPED, the Ministry of Local Government, the National Planning Authority, the Office of Prime Minister, the Ministry of Public Service, the Uganda Local Governments Association, civil society, and development partners. This committee provides overall strategic guidance to the programme and civil society has been very active at influencing and advocating for the programme within this structure (ESP, 2013a).

DFID has supported the formation of the Uganda Social Protection Platform (USPP) through which CSOs have been able to advocate for social protection programmes, specifically the roll-out of the Senior Citizen Grant (SCG) nationally. Most of the advocacy work has been targeting politicians such as Members of Parliament (MPs) and Minister of Finance, Planning and Economic Development to influence the prioritisation and allocation of more financial resources to the SAGE. The advocacy has been done through different approaches that include writing letters to the President and Minister of Finance, Planning and 
Economic Development. In November 2014, a petition calling for the national roll-out of SCG was tabled for discussion and debate in Parliament by the Chairperson of the Uganda Parliamentary Forum on Social Protection. It was later forwarded for handling to the Parliamentary committee on Gender, Labour and Social Development. In 2014, the USPP engaged in a range of advocacy activities that included petitioning the Speaker of Parliament, district leaders and MPs, dialogues with political parties, engagement with the Uganda Local Government Association, and SAGE monitoring in selected districts.

Platforms have not stopped with CSOs but (also with DFID support) a Uganda Parliamentary Forum on Social Protection has been formed. This body brings together Members of Parliament (MPs) with an interest in, and who support, social protection. The forum was launched early in 2014 and at the time of this research had over 40 members. The formation of such a forum that brings together members of parliament is an indication that social protection programmes (and specifically SAGE) had gained political acceptance in Uganda.

During the launch of the Forum, the Speaker challenged MPs who are members of the Forum to ensure that they lobby for funding for social protection so that the SCG is rolled out as a national social pension. The speaker said that "all older persons in all districts around the country deserve the grants and there is need to ensure that a budget is allocated to cover all senior citizens in all the districts of the country" ${ }^{30}$ A number of MPs have called for the allocation of more funds to the SAGE programme. For example, early in 2014, during a press conference held at Parliament, the Chairperson of the Uganda Parliamentary Forum on Social Protection said that "We want a national roll out so that all elder persons can benefit from this money. Only 14 districts out of 112 districts are benefitting, which is a small number. This money is spent on health care, building houses and supporting the elderly people". ${ }^{11}$

\subsubsection{Evolving arguments in favour of cash transfers}

Cash transfers have increasingly been presented as a 'developmental intervention' by its proponents. Social protection is increasingly presented as a necessary complement, rather than an alternative, to investment in the productive sectors of the economy. Anecdotal evidence that the SAGE grants have helped revitalise the local economy in pilot districts are frequently cited. Tellingly, when speaking

\footnotetext{
${ }^{30}$ Audio Recording of speech delivered at launch of the Uganda Parliamentary Forum on Social Protection. A report on the launch is also available at:

http://www.socialprotection.go.ug/Parliamentary\%20Forum\%20on\%20Social\%20Protection \%20launched.pdf

${ }^{31}$ Audio recording of press conference.
} 
about the impacts of SAGE, ESP officials and other supporters of the programme (including MPs) frequently mention reports that some beneficiaries have pooled pay-outs in informal saving schemes from which loans are then taken to purchase productive assets like livestock. Evidence of these schemes among beneficiaries is largely anecdotal, but it appears to be used both as a powerful rhetorical device to counter the notion that beneficiaries 'waste' cash 'hand-outs', and to show that cash transfers can contribute to development. Similarly, results of 'exit surveys' of beneficiaries' expenditure patterns that show 'non-wasteful' and productive spending is seen as powerful evidence in favour of the programme. The MGLSD emphasises four economic impacts of SAGE: (1) increased household productivity through investment in agriculture and small business enterprises, (2) increased savings and investment in higher-risk ventures, (3) large numbers of savings and loans groups among beneficiaries, and (4) increased demand for local goods and services (Okillan, 2014).

For example, Beatrice Okillan, in her presentation to MPs at the launch of the Parliamentary Forum, emphasised the use of money received through SAGE to buy productive assets such as livestock (Okillan, 2014). Social protection came to be presented as a necessary complement, rather than an alternative, to investment in the productive sectors of the economy. Some evidence of success in making this argument is provided by the fact that even a recent Poverty Status Report published by the Finance Ministry argued that addressing household vulnerability was essential for economic development, especially by enabling households to make riskier investments (MFPED, 2012). In the report's foreword it was stated that:

'Convincing evidence is presented that the transformation process is well underway - there has been dramatic growth and diversification of the non-agricultural economy. ... Uncertainty deters investment... The new evidence in this report (both quantitative and qualitative) illustrates the importance of microeconomic stability - the volatility at the level of the household' (MFPED, 2012: i).

\subsubsection{Rise of the 'inclusive development' agenda}

During the fieldwork for this research, interviews with key informants indicated a growing acceptance that certain sections of the population were unlikely to benefit much (at least in the short to medium term) from economic development. The phrase 'inclusive development' was in wide use, with cash transfers seen as one way to ensure that the most marginalised are not left entirely out of the development process. Despite the move away from a focus on poverty reduction, there appeared to be wider acceptance that investment in infrastructure and private 
sector development would most benefit those of working age and in regions where economic activity is not restricted to agriculture. This may help to explain why cash transfers to the aged were more widely accepted, while even among some of the strongest supporters of social protection cash transfers continued to be considered inappropriate for other groups. As Sarah Nahalamba (Senior Planner in the National Planning Authority) put it:

'We have changed our development paradigm to focus on growth. But of course, inclusive growth is something we are pushing forward. Because inclusive growth means poverty issues have to be addressed. You may have growth that is not inclusive. ... That is why we are so interested in some of these social policies [like cash transfers] that can help us strike a balance between economic growth and social welfare. ... [For these reasons] we have integrated social protection into the national planning framework' (Interview, 20 January 2014).

\subsubsection{Increasing familiarity with and improved evidence for the feasibility efficacy of cash transfers}

Research and information provision: In order to change policy-makers' mind-sets as well as provide more information about social protection and its importance in developing countries such as Uganda, both the Social Protection Secretariat and CSOs like DRT have organised workshops targeting different stakeholders with different messages. These meetings have been backed up with the production of various advocacy materials including policy briefs, discussion papers, information, education, and communication materials, as well as research reports on the impacts of SAGE. For example, when some politicians were saying that social protection is a western-driven agenda, DRT and Cross Cultural Foundation of Uganda (CCFU) undertook a joint study in 2007 on "Culture and Social Protection for the poor in Uganda" to demonstrate that social protection is not a foreign concept but rooted within Uganda's traditional systems and practices (cited in Onapa, 2010). Other studies which were aimed at providing evidence and information on the need for social protection in Uganda included "Social Protection in Uganda: A call for Action", by DRT (Onapa, 2010). In order to attract wider attention to social protection issues, DRT carried out a series of workshops in the different regions of Uganda targeting district politicians, technocrats and CSO representatives. The intention was to create knowledge and an understanding on social protection through provision of information as well as stimulating debates and demand for social protection initiatives. In addition, CSOs provided information to the government through the Civil Society Issues Paper on social protection to inform the design of National Development Plan, specifically on the Social Protection theme. 
Donors and CSOs have organised a number of conferences to provide evidence on successful social protection schemes and its affordability in developing countries. These include the most recent regional conference on "Financing Social Protection in East and Central Africa: Learning from experience" held in October 2013. It was organised by DRT and the Economic Policy Research Centre (EPRC) at Makerere University, with support from the Think Tank Initiative at International Development Research Centre (IDRC) and the Friedrich Ebert Stiftung (FES). The purpose of the conference was to stimulate discussion and learning about various options of financing of social protection programmes particularly in low income countries, especially in Eastern and Central Africa. The conference was attended by delegates including social protection experts from a range of countries such as Kenya, Tanzania, Zambia, Mauritius, South Africa and Malawi. Experiences were shared on what has worked in each of these countries. Previous conferences include the First International Conference on Social protection for the Poorest in Africa that was organised by DRT in partnership with the Chronic Poverty Research Centre (CPRC), Brookes World Poverty Institute (BWPI), the Ministry of Finance, Planning and Economic Development, Swiss Development Cooperation, and UNICEF. This conference was aimed at furthering learning on social protection. It targeted a number of stakeholders including politicians and government institutions such as the MGLSD and MFPED.

Study trips for politicians and technocrats: In a bid to create understanding of social protection and its importance, a number study trips to other countries where social protection programmes have been successfully implemented have been carried out. These were aimed at building increased political will. DFID funded a study tour for key government officials to Malawi in order to observe the Mchinjiji Cash Transfer project in 2007. This exposure increased the appreciation of, and interest in, social protection among delegates, who are reported to have become important advocates of cash transfers in Uganda (Onapa, 2010).

The Social Protection Secretariat has also organised study trips in order to build political support. For example, in November 2011 a Uganda delegation comprising six cabinet members and two MPs visited South Africa and Lesotho to learn about the direct income support programmes in the two countries. On return from the study trip, one of the delegates said that "the government of Uganda should prioritise direct income support to older persons and commit to immediate but phased scale up of SAGE" (ESP, 2013a). In February 2014, the Social Protection Secretariat organised another study trip to Mauritius and South Africa for politicians, to increase understanding of the strategic importance of direct income support - a key social protection instrument, and how it has 
contributed to the development of those two countries. The delegates included Ministers and senior officials from a range of departments. ${ }^{32}$

\subsubsection{Improved institutional capacity}

Training conducted by key stakeholders such as the Social Protection Secretariat has also helped increase domestic political support for the SAGE pilot programme in Uganda.

Leadership capacity development activities have been carried out at various levels, from national to district and local government levels. A significant amount of training has been conducted for different stakeholders, both inside government and outside, for the purposes of implementation and monitoring of the programme. In the wider government, people have been trained across the ministries and these training activities have attracted high-level officers, Permanent Secretaries, Directors, Commissioners, and Assistant Commissioners. Others have attended a special course conducted by the Economic Policy Research Institute (EPRI) based in Cape Town, South Africa.

The Social Protection Secretariat has developed a course conducted locally, called 'Social Transfers: Policy and Programming in Uganda'. This course is intended to significantly expand the number of Ugandan officials who have received comprehensive training in the key social protection policy issues in Uganda. For example in December 2011, the first session of the course attracted over 42 participants from various government departments. The training was conducted by the Social Protection Secretariat in conjunction with the Intergovernmental Authority on Development (IGAD), and delivered by Development Pathways, a group of experienced international development practitioners specialising in the social protection field and social development (ESP, undated web page).

\footnotetext{
${ }^{32}$ The delegation comprised Hon. Mary Karooro Okurut, Minister of Gender, Labour and Social Development, Hon. Richard Todwong, Minister for political Mobilisation, Office of the president, Hon. Rose Namayanja, Minister of Information and National Guidance, Hon. Sulaiman Madada, Minister of State for Gender, Labour and Social Development in charge of Elderly and Disability affairs, Hon. Margaret Komuhangi, Member of Parliament, and the Chairperson Parliamentary Committee on Gender, Labour and Social Development. Other members of the team included Mr. Pius Bigirimana, Permanent Secretary-Ministry of Gender, Labour and Social Development, Mr. Kenneth Mugambe, Director of Budget, Ministry of Finance, Planning and Economic Development, Mr. Daniel Graymore, Head of Office, DFID Uganda, Mr. Donal Cronin-Chargé d'Affaires, Embassy of Ireland, Mr. Stephen Kasaija-Head, Social Protection Secretariat, Ministry of Gender Labour \& Social Development, among others.
} 
Training has also targeted politicians, especially at the local government level. These include the chairpersons and councillors at various levels - district, subcounty, parish, and village level (ESP, 2013b). This was done because local political leaders play an important role in overseeing and supporting development activities within their districts. SAGE has engaged the political leaders in carrying out monitoring activities. Furthermore, the district SAGE support unit shares regular performance reports with the district political leadership through the Chief Administrative Officer (CAO). Work plans, budgets, and minutes of the quarterly SAGE programme management meetings are also copied to the district chairperson and the social service committee of district councillors (MGLSD, 2012b).

\subsubsection{Electoral politics}

Public demand and the perceived electoral advantages of supporting the pilot and its expansion also appeared to play a role in rising political support. The SAGE pilot was widely seen by informants (including Members of Parliament) as an extremely popular programme that had greatly enhanced the visibility of the government in the remote and rural communities where many beneficiaries live. Many informants attributed the growing political support for the pilot - especially in Parliament - to politicians noticing its popularity and potential as a votewinner. Some MPs argued that it would be 'political suicide' to oppose the programme in interviews. In fact, the NRM, the Forum for Democratic Change (the official opposition), and the Uganda People's Congress all included commitments to social pensions in their election manifestos for the 2011 election, with the FDC even including the specific commitment of doubling the size of the monthly payment. ${ }^{33}$ Social pensions were seen as popular not only among direct beneficiaries, but also among those on whom old age poverty creates a burden: communities and kin (especially children) who are traditionally expected to support the elderly. ${ }^{34}$ Many respondents cited the 2016 election cycle as a factor working in favour of the pilot and of the potential national rollout of a social pension, since politicians would be looking to claim credit for successful and visible interventions, and the pilot comes at relatively low cost.

However, the literature on electoral politics in Uganda suggests a less neat link between electoral pressure and 'popular' or 'vote-winning' policies. Neither President Museveni (in the competitive presidential elections since 1996) nor the

\footnotetext{
33 The NRM's election manifesto states that "The NRM Government will roll out the cash transfer program for older persons" (NRM, 2010: 41) and the FDC's that it "will pay USh 50,000 per month to persons over 65 years" (FDC, 2010: 20). The UPC's also commits to a national social pension (UPC, 2010).

${ }^{34}$ Interview, Joseph Mugisha-Bitature (27 January 2014)
} 
NRM (in multiparty legislative elections since 2006) have faced a serious electoral threat from opposition parties. Rakner and Helle (2013) argue that the low level of urbanisation in Uganda has allowed the incumbent party to effectively use the 'authoritarian tools' at its disposal during the 2011 election (in contrast to Zambia, which saw similar levels of opposition mobilisation and where the opposition in fact won the election). As Gibb (2012: 460) points out, in the 2011 Presidential election Museveni attracted only a slightly greater percentage of the vote than the Afrobarometer survey suggested he should - showing that the President truly is popular among the voting population, especially rural voters. Furthermore, the only contests marked by serious violence and repression were those during NRM primaries for party candidacies and the mayoral election in Kampala (won by an opposition candidate) - pointing, according to Gibb (2012: 461 , to the importance of primary elections in a system where a single party dominates government decisions and patronage networks. This chimes with Golooba-Mutebi and Hickey's (2013) description of the political settlement in Uganda as a 'dominant president form' with increasing 'competitive clientalist tendencies', if the competitive dimension of clientalism is seen as occurring primarily within the ruling party. They further suggest that this can result in propoor outcomes, as political competition (whether electoral or over patronage benefits) may create incentives for politicians to be seen to support pro-poor and pro-rural policies - as cash transfers are. Stasavage's (2005) analysis of the 1996 Presidential election suggest that even in the absence of a significant challenge to Museveni, Uganda's move to Universal Primary Education (UPE) - and associated massive increases in expenditure on primary education - can indeed be linked to democratic politics, but that it depended on the salience of education as an issue and the public's access to information about UPE.

The move to multiparty democracy may have been driven primarily by internal factional conflicts within the NRM, coupled with constitutional changes designed to safeguard the power of the Executive and the central political leadership (Makara et al., 2009). Repression of political opposition continues in Uganda (Izama and Wilkerson, 2011) - allegations of systematic human rights violations are common (see Human Rights Watch, 2011) and Freedom House has consistently rated civil and political rights poorly ${ }^{35}$ - which makes an opposition victory extremely unlikely. Nevertheless, the impact of electoral politics cannot be entirely discounted. Read as a whole, the somewhat contradictory literature on electoral politics in Uganda suggests that even in the context of Museveni and the NRM being assured of an election victory in 2016, if old age poverty becomes a sufficiently salient issue, and it is judged electorally advantageous by NRM

\footnotetext{
${ }^{35}$ Freedom House political rights and civil liberties ratings for Uganda varied between 4 and 6 since 1986 and stood at 6 and 4 respectively in 2014. Ratings are on a 7-point scale with 1 representing most free and 7 least free. Uganda was classified as 'partly free' throughout the period (Freedom House, 2014).
} 
candidates to support a social pension in competitive primaries (or in the actual elections in those constituencies that are genuinely competitive), electoral forces may well favour the introduction of such a social pension. Judging by newspaper coverage of old age poverty and the SAGE pilot, the public salience and access to information about old age poverty and the social pension appears to be risingalthough rigorous evidence of this is lacking.

A number of politicians have been quoted saying that the SAGE programme is safe and expansion likely because of the NRM Manifesto commitment to older persons. This was evident during a visit to Kiboga (one of the SAGE pilot districts) by the previous Minister of Gender, Labour and Social Development(ESP, 2013c). The SAGE programme has recently gained political support in different ways within the NRM. For example, following the successful setup of delivery systems and processes in Kaberamaido, Kiboga, and Kyenjojo district, the programme was officially launched by Vice President Edward Kiwanuka Ssekandi on behalf of the President in October 2011. In March 2012, Museveni himself launched the programme in Nebbi district (ESP, 2013b). Several politicians have been seen participating in the launch of the SAGE programme in pilot districts. These include the Prime Minister, Amama Mbambazi, who made the first payment of the Senior Citizen Grant in Kyankwanzi district in October 2012.

Some politicians have praised both the implementation and the impact of the SAGE programme. For example, during a visit to Nebbi-one of the pilot SAGE districts in July 2013 the Minster of Gender, Labour and Social Development, Mary Karooro Okurut, said:

'I am impressed by the work done by SAGE in Nebbi district. I have seen from my interaction with beneficiaries that they are putting the money they receive to good use. As government, we are committed to ensuring that the programme goes ahead and is scaled to other districts in the country' (ESP, 2013c).

A national social pension (usually framed as a national rollout of the SCG) is firmly on the political agenda in Uganda. In August 2013 the President of Uganda directed the Ministry of Gender, Labour and Social Development to expand the programme to Yumbe district. To respond to the President's directive, the Ministry decided to use the USh $2 b$ that was allocated in the 2013/14 financial year as counterpart funding by the government to implement the programme in the fifteenth district. Recent evidence from Yumbe district indicates that preparations for the rolling out of the Senior Citizen Grant are progressing. According to a Yumbe District Community Development Officer, the local council leaders and key stakeholders had been trained in the operational 
modalities of the programme, beneficiaries had already been identified (ESP, 2013c), and the first payments were made in August 2014 (ESP, 2014).

Most significantly, the President of Uganda has also directed the MGLSD and MFPED to jointly develop a national roll-out plan for the Senior Citizen Grant and to publish the agreed roll-out plan in the media. In response to the President's directive, the two ministries carried out a study 'Cost and Financing Options on affordability of the national Senior Citizen Grant' to complement the existing financing options study (Cammack and Twinamatsiko, 2013). It was concluded that the government of Uganda can afford to roll out the programme (Okillan, 2014). The report indicates that the programme can be fully financed from projected increases in revenue alone and would cost a maximum of $6.88 \%$ of the annual revenue increase, dropping to only around $2 \%$ of the annual revenue increase from 2019/20 onwards. Therefore, the national roll-out of the programme could be implemented without the need for reallocating any existing expenditure or relying on development partners or borrowing. At full scale, the study concluded that a national senior citizen grant would cost only $2.09 \%$ of the total government expenditure and $3.76 \%$ of the recurrent expenditure (Cammack and Twinamatsiko, 2013).

These emerging events seem to indicate that SAGE, and especially the national rollout of a social pension, is widely perceived as something that could provide significant political capital and electoral advantage. Given a widely-held perception that Government initiatives are credited to the NRM and even President Museveni himself, the claim of certain respondents that the President is likely to announce a national social pension before the 2016 elections does not seem unreasonable.

\section{Conclusion}

The evolution of social protection in Uganda can be traced back to traditional cultural norms that included solidarity and assistance to people within clans, extended families, and broader society who were unable to look after themselves. Colonial and postcolonial social security systems largely left what we now call social protection for the poorest to kin and tribe, while a small elite of civil servants (and later formal sector workers) had access to social insurance.

Only since the early 2000 s has social protection gained in prominence as a tool for poverty eradication and inclusive development. We traced this slow evolution of development policy to embrace social assistance and cash transfers in order to demonstrate that substantial resistance existed amongst technocratic and political 
elites and that these were to some extent overcome by the proponents of cash transfers.

The sources of resistance to cash transfers (and social protection for the poorest more broadly) are varied and complex. That it existed is clear from donors' failed attempts to implement large-scale programmes before the SAGE pilot started in 2010. It is our contention that, in addition to legitimate concerns over the affordability and sustainability, the prevailing development 'paradigm' and 'discourse', negative elite attitudes to and lack of familiarity with social assistance, as well as intra-governmental institutional politics probably played significant roles. This is an area that requires further research into the continuing resistance to cash transfers from some technocrats and political leaders in order to be fully understood.

We further identified a number of potentially crucial factors that may help explain the substantially increased levels of political support for social protection for the poor, and cash transfers in particular, that can be observed from the mid-2000s onwards and especially since the implementation of SAGE started. Our informants were nearly unanimous that there had been a massive change in the attitudes of policy-makers and politicians. There is sufficient evidence to conclude that donor and bureaucratic advocacy (see also Grebe, 2014a), civil society advocacy and supportive politicians, and evolving arguments in favour of, and increased evidence on, the efficacy and affordability of cash transfers have positively and substantially impacted on the political appetite for social protection for the poor, and cash transfers in particular. It is harder to substantiate that electoral politics has been an important driver of the increased domestic political support, although we believe the indications are strong that this has been an important factor.

Unfortunately, weighing up the relative importance of these political factors and forces is not possible using the available data. We are also not currently in a position to compare Uganda to similar Sub-Saharan African countries in order to shed further light on these political factors (for example by identifying the ways in which it has been typical and exceptional). Further research is required in order to form a more comprehensive understanding of the political drivers of domestic political support for social protection and cash transfers. The factors identified in this paper, while treated somewhat speculatively, are nevertheless a useful starting point to inform this broader research agenda.

It is further worth noting that while the evidence presented in this paper has demonstrated fairly conclusively that political support for social protection (which includes social assistance in the form of cash transfers to the poorest) has been rising, the broader development policy discourse is still dominated by an 
'economic growth and prosperity' agenda, and it appears that public investment in infrastructures such as roads and electrification may well be a greater priority. This is reflected in the National Development Plan and the rhetoric emanating from senior figures in the Executive, including the President himself, which leaves investment in social protection as a far lower priority.

We conclude, therefore, that it is too early to proclaim that donor, civil society, and bureaucratic advocacy, or other political factors such as increasing awareness of international evidence and perceived electoral advantages, have resulted in a reorganisation of developmental priorities in Uganda. The future of social protection programmes depend on political and fiscal commitments that have not yet been demonstrated. We can merely say that social protection has attracted significantly higher levels of political support in recent years than in the past, and that future investment in large-scale social assistance has become more likely than at any previous point in Uganda's history.

\section{Appendix: Timeline of key policy developments (1986-2014)}

1986: NRM/Museveni regime comes to power

1987: Package of structural adjustment reforms agreed with IMF

1992: MFPED established after merger

1992: Medium Term Expenditure Frameworks introduced

1993: Initiation of a privatisation programme

1993: Decentralisation of service delivery

1995: Etandwikwa programme (micro-credit scheme)

1995: Consultative Group meeting in Paris

1995: National Task Force on Poverty Eradication

1996: Museveni pledges Universal Primary Education

1996: Presidential election

1997: Poverty Eradication Action Plan ( $1^{\text {st }}$ version $)$

1998: Uganda Participatory Poverty Assessment Project

1999: Vision 2025

1999: $1^{\text {st }}$ Poverty Status Report

1999: PEAP revision initiated

2000: UPPAP report \& $2^{\text {nd }}$ phase

2000: PEAP draft $1^{\text {st }}$ revision recognised as Poverty Reduction Strategy Paper

by World Bank \& IMF

2001: Poverty Eradication Action Plan 2001-2003 ( $1^{\text {st }}$ revision)

2001: Presidential election

2001: $2^{\text {nd }}$ Poverty Status Report 
2002: Social Protection Task Force established

2003: $3^{\text {rd }}$ Poverty Status Report

2004: Poverty Eradication Action Plan ( $2^{\text {nd }}$ revision)

2005: WB Board accepts $2^{\text {nd }}$ revision of PEAP

2006: General election (presidential \& multiparty parliamentary)

2006: Transformation of Social Protection Task Force into the Social Protection

Sub-committee in the Social Development Sector Working Group

2007: Proposed cash transfer pilot (blocked by Minister of Finance)

2010: National Development Plan 2010/1-2014/5

2010: Expanding Social Protection Programme (ESP) approved by Cabinet

2011: Launch of the $2^{\text {nd }}$ Social Development Sector Strategic Investment Plan (SDIP 2) 2011/12-2015/16

2011: General election (presidential \& multiparty parliamentary)

2011: SAGE transfers initiated under ESP

2012: First draft of Social Protection Policy Framework

2013: Vision 2040

2013: Third draft of Social Protection Policy Framework

2013: Draft rollout plan for national SCG prepared by MGLSD

2014: Draft rollout plan for national SCG publicly presented by MGLSD (Feb.)

2014: Uganda Parliamentary Forum for Social Protection launched (Feb.)

2014: Draft second National Development Plan (2015/16-2019/20) produced

2014: Senior Citizen Grant launched in Yumbe District by the Minister of Finance (Oct.)

2014: Chairperson of the Uganda Parliamentary Forum for Social Protection presents a petition to roll out the SCG in Parliament (Nov.)

2014: $2^{\text {nd }}$ Poverty Status Report launched by MFPED (Dec.) 


\section{References}

Barya, J.J. 2009. Interrogating the Right to Security and Social Protection in Uganda. HURIPEC Working Paper No. 23.

Batana, Y.M., Cockburn, J., Kasirye, I., Tiberti, L. \& G. Ahaibwe. 2014.

Situation Analysis of Child Poverty and Deprivation in Uganda. Partnership for Economic Policy (PEP) Working paper 2014-03. Available at:

http://papers.ssrn.com/sol3/papers.cfm?abstract_id=2463210

Blattman, C., Fiala, N. \& S. Martinez. 2009. Impact Evaluation of the Northern Uganda Social Action Fund Youth Opportunities Project, Uganda. World Bank Social Protection Discussion Paper No. 1120.Washington, D.C.: World Bank. Available at:

http://siteresources.worldbank.org/EXTHDOFFICE/Resources/54857261334870720628/8597105-1334870749247/Uganda_Evaluation_Report.pdf

Bukuluki, P. \& C. Watson. 2012. Transforming Cash Transfers: Beneficiary and community perspectives on the Senior Citizen Grant (SCG) in Uganda. London: Overseas Development Institute.

Cammack, T. \& F. Twinamatsiko. 2013. Uganda Social Protection Financing Options Study: Final Report. Kampala: Expanding Social Protection Programme, Ministry of Gender, Labour and Social Development.

CPAN. 2013. The $2^{\text {nd }}$ Chronic Poverty Report-Uganda: Is Anybody Listening? Kampala: Chronic Poverty Advisory Network.

CPRC Uganda. 2005. Chronic Poverty in Uganda: The Policy Challenges. Kampala: Chronic Poverty Research Centre Uganda. Available at: http://www.chronicpoverty.org/publications/details/chronic-poverty-in-ugandathe-policy-challenges/ss

Deininger, K. 2003. Does cost of schooling affect enrolment by the poor? Universal primary education in Uganda. Economics of Education Review 22(3): 291-305.

Devereux, S. \& R. Sabates-Wheeler. 2002. Social Protection in Uganda: Study to Inform the Development of a Framework for Social Protection in the Context of the Poverty Eradication Action Plan. Phase I Report - Vulnerability Assessment $\&$ Review of Initiatives. Kampala: Social Protection Task Force. 
Devereux, S. \& R. Sabates-Wheeler. 2003. Social Protection in Uganda. Facilitating the Process of Mainstreaming Social Protection into the PEAP Revision. Phase II Report - A Vulnerability Issues Paper. Kampala: Social Protection Task Force.

Devereux, S. \& R. Sabates-Wheeler. 2004. Poverty Eradication Action Plan (20 March 2004 Draft): The Consultative Process, Policy Recommendations and the Way Forward. Kampala: Social Protection Task Force.

Devereux, S., Lwanga-Ntale, C.L. \& R. Sabates-Wheeler. 2002. Social Protection in Uganda: Study to Inform the Development of a Framework for Social Protection in the Context of the Poverty Eradication Action Plan. Phase I Report: Vulnerability Assessment \& Review of Initiatives. Kampala: Social Protection Task Force.

DRT (Development Research and Training). 2006. Vulnerability and Poverty Analysis: A needs Assessment for Designing a Cash Transfer Scheme to address Chronic Poverty in Uganda. Kampala: Development Research and Training.

ESP (Expanding Social Programme). 2011. ESP NEWS: A Newsletter of the Expanding Social Protection Programme (August 2011). Kampala: Expanding Social Protection Programme, Ministry of Gender, Labour and Social Development. Available at:

http://www.socialprotection.go.ug/pdf/Newsletters/ESPNewsletterAugust2011.p $\underline{\mathrm{df}}$

ESP. 2012. ESP NEWS: A Newsletter of the Expanding Social Protection Programme (July 2012).Kampala: Ministry of Gender, Labour and Social Development. Available at: http://www.socialprotection.go.ug/pdf/Newsletters/ESPNewsletterJuly2012.pdf

ESP. 2013a. A brief on Expanding Social Protection Programme and its strategic role in Uganda's development. Kampala: Expanding Social Protection Programme, Ministry of Gender, Labour and Social Development.

ESP. 2013b. ESP NEWS: A Newsletter of the Expanding Social Protection Programme (April 2013). Kampala: Expanding Social Protection Programme, Ministry of Gender, Labour and Social Development. Available at: http://www.socialprotection.go.ug/pdf/Newsletters/ESPNewsletterApril2013.pdf

ESP. 2013c. ESP NEWS: A Newsletter of the Expanding Social Protection Programme (September 2013). Kampala: Expanding Social Protection Programme, Ministry of Gender, Labour and Social Development. Available at: 
http://www.socialprotection.go.ug/pdf/Newsletters/ESPNewsletterSeptember20 13.pdf

ESP. 2014. ESP NEWS: A Newsletter of the Expanding Social Protection Programme (September 2014). Kampala: Expanding Social Protection Programme, Ministry of Gender, Labour and Social Development. Available at: http://www.socialprotection.go.ug/pdf/Newsletters/SP\%20Newsletter\%20press. pdf

ESP. undated. Income Security for All Ugandans in Old Age. Kampala: Expanding Social Protection Programme, Ministry of Gender, Labour and Social Development. Available at:

http://www.socialprotection.go.ug/pdf/Policy\%20publications/The\%20Case $\% 20$ for $\% 20$ Income $\% 20$ Security $\% 20$ for $\% 20$ all $\% 20$ Ugandans $\% 20 \mathrm{in} \% 2001 \mathrm{~d} \% 20 \mathrm{Age}$ .pdf

ESP. undated. Policy and Institutional Development. Web page. Available at: http://www.socialprotection.go.ug/policy\%20and\%20institutional\%20developm ent.php [Accessed 15 April 2014].

FDC (Forum for Democratic Change). 2010. Manifesto 2011-2016. Kampala: Forum for Democratic Change.

Ferguson, J. 2012. 'What Comes after the Social? Historicizing the Future of Social Assistance and Identity Registration in Africa'. In Breckenridge, K. \& S. Szreter (eds.) Registration and Recognition: Documenting the Person in World History. Oxford: Oxford University Press.

Freedom House. 2014. Freedom in the World: Country Ratings and Status, FIW 1973-2014 [Excel spreadsheet]. Available at:

http://www.freedomhouse.org/report-types/freedom-world

Gibb, R. 2012. Presidential and parliamentary elections in Uganda, February 18, 2011. Electoral Studies, 31(2): 245-468.

Golooba-Mutebi, F. \& S. Hickey. 2010. Governing Chronic Poverty under Inclusive Liberalism: The Case of the Northern Uganda Social Action Fund. Journal of Development Studies, 46(7): 1216-1239.

Golooba-Mutebi, F. \& S. Hickey. 2013. Investigating the links between political settlements and inclusive development in Uganda: towards a research agenda. ESID Working Paper No. 20. Manchester: Effective States and Inclusive Development Research Centre, University of Manchester. 
GoU (Government of Uganda). 2010. National Development Plan (2010/112014/15). Kampala: Government of Uganda.

GoU. 2013. Uganda Vision 2040. Kampala: Government of Uganda.

Grant, U. 2006. Research into policy processes: Bringing Global Evidence on Social Protection into Local Policy Contexts. Background Paper for the Chronic Poverty Report 2008-09. Manchester: Chronic Poverty Research Centre. Available at: http://www.odi.org/sites/odi.org.uk/files/odi-assets/publicationsopinion-files/3250.pdf

Grebe, E. 2014a. Donor agenda-setting, bureaucratic advocacy and cash transfers in Uganda, 2002-2013. CSSR Working Paper No. 352. Cape Town: Centre for Social Science Research, University of Cape Town. Available at: http://cssr.uct.ac.za/pub/wp/352

Grebe, E. 2014b. Civil society and the state in Uganda's AIDS response. CSSR Working Paper No. 341. Cape Town: Centre for Social Science Research, University of Cape Town. Available at: http://cssr.uct.ac.za/pub/wp/341.

Hickey, S. 2012. Beyond the Poverty Agenda? Insights from the New Politics of Development in Uganda. World Development, 43: 194-206.

Hickey, S., Sabates-Wheeler, R., Guenther, B. \& I. Macauslan. 2009. Promoting Social Transfers: DFID and the Politics of Influencing. DFID Working Paper No. 32. London: Department for International Development.

Huda, K., Onapa, P., Sanyu, R. \& B. Mugambe. 2013. The implementation of social protection: Realizing commitments made in the NDP (2010/11 to 2012/13). Kampala: National Planning Authority.

Human Rights Watch. 2011. Violence Instead of Vigilance: Torture and Illegal Detention by Uganda's Rapid Response Unit. New York, NY: Human Rights Watch. Available at: http://www.hrw.org/en/reports/2011/03/23/violenceinstead-vigilance

Izama, A. \& M. Wilkerson. 2011. Uganda: Museveni's Triumph and Weakness. Journal of Democracy, 22(3): 64-78. 
Kakande, M. 2011 Poverty Monitoring. In Kuteesa, F., Tumusiime-Mutebile, E., Whitworth, A. \& T. Williamson (eds.) Uganda's Economic Reforms: Insider Accounts. Oxford: Oxford University Press.

Kasaija, S. 2014. Uganda's Experience in Social Protection: Integrating Social Protection in national development planning. A presentation to the international conference on Social Protection: Building Effective and sustainable systems for equitable growth. Social Protection: Building Effective and Sustainable Systems for Equitable Growth: Perspectives, Policies and Best Practices, December 1517, Arusha, Tanzania.

Kasekende, L.A. \& M. Atingi-Ego. 2008. Restarting and sustaining growth in a post-conflict economy: the case of Uganda. In Ndulu, B.J., O'Connell, S.A., Azam, J-P., Bates, R.H., Fosu, A.K., Gunning, J.W. \& N. Dominique (eds.) The Political Economy of Economic Growth in Africa, 1960-2000. New York: Cambridge University Press, pp. 244-285.

Kidimu, G. 2013. Workers to benefit from pension reforms. New Vision, September 12. Available at:

http://www.newvision.co.ug/news/647173-workers-to-benefit-from-pensionreforms.html

Lwanga-Ntale, C. 2008. The Imperative of Winning Political Support for Social Protection in Uganda. Social Protection for the Poorest in Africa: Compendium of Papers Presented during the International Conference of on Social Protection ( $8^{\text {th }}-10^{\text {th }}$ September, 2008), pp. 290-299.

Makara, S., Rakner, L. \& L. Svåsand. 2009. Turnaround: the NRM and the reintroduction of a multiparty system in Uganda. International Political Science Review, 30(2):. 185-204.

Mamdani, M. 1976. Politics and Class Formation in Uganda. Kampala: Fountain Publishers.

Maxwell Stamp. 2010. Job Description: Assignment Title: Expanding Social Protection in Uganda; Proposed Job Title: M\&E Coordinator. Web page: devex [Job advertisement from Maxwell Stamp PLC]. Available at: https://www.devex.com/jobs/monitoring-evaluation-expert-225479.

McCord, A., Onapa, P. \& S. Levine. 2013. NUSAF 2 Public Works Programme (PWP) Design Review. London: Overseas Development Institute. Available at: http://www.drt- 
ug.org/book_files/Finalised\%20NUSAF\%202\%20PWP\%20Design\%20Review \%20April\%202013.pdf

Melo, M.A., Ng'ethe, N. \& J. Manor. 2013. Against the Odds: Politicians, Institutions and the Struggle Against Poverty. London: Hurst \& Company.

MFPED (Ministry of Finance, Planning and Economic Development). 1997. Poverty Eradication Action Plan. Kampala: Ministry of Finance, Planning and Economic Development. Kampala: Ministry of Finance, Planning and Economic Development.

MFPED. 1999. Poverty Status Report. Kampala: Ministry of Finance, Planning and Economic Development.

MFPED. 2004. Poverty Eradication Action Plan (2004/5-2007/8). Kampala: Ministry of Finance, Planning and Economic Development.

MFPED. 2012. Poverty Status Report: Poverty Reduction and the National Development Process. Kampala: Economic Development Policy and Research Department, Ministry of Finance, Planning and Economic Development. Available at: http://www.opendev.ug/sites/opendataug01.drupal01.mountbatten.ug/files/poverty_status_report_2012.pdf

MFPED. 2013. Millennium Development Goals Report for Uganda 2013: Drivers of MDG progress in Uganda and Implications for post-2015 Development Agenda. Kampala: Ministry of Finance, Planning and Economic Development. Available at: http://www.ug.undp.org/content/dam/uganda/docs/UNDPUg2013MDGProgress\%20Report-Oct\%202013.pdf

MFPED. 2014. Poverty Status Report 2014. Kampala: Ministry of Finance, Planning and Economic Development. Available at:

http://www.finance.go.ug/index.php?option=com_docman\&Itemid=7\&task=doc download\&gid $=423$

MGLSD. 2003. The Social Development Sector Strategic Investment Plan $(S D I P)$. Kampala: Ministry of Gender, Labour and Social Development.

MGLSD. 2007. Design of a Cash Transfer Pilot for Uganda. Kampala: The Uganda Social Protection Task Force, Ministry of Gender, Labour and Social Development. 
MGLSD. 2009. National Policy on Disability in Uganda. Kampala: Ministry of Gender, Labour and Social Development. Available at:

http://www.mglsd.go.ug/wpcontent/uploads/2013/07/policies/NATIONAL\%20POLICY\%20ON\%20DISAB $\underline{\text { ILITY\%20January,\%202006.pdf }}$

MGLSD. 2010. OVC Situation Analysis Report 2009/10. Kampala: Ministry of Gender, Labour and Social Development.

MGLSD. 2011a. Issues paper: Strengthening human resource and financing for child care and protection services. Kampala: Ministry of Gender, Labour and Social Development. Available at: http://ovcsupport.net/wpcontent/uploads/Documents/Issues_Paper_August_2011_Strengthening_Human _Resources_and_Financing_for_Childcare_and_Protective_Services_1.pdf

MGLSD. 2011b. The Social Development Sector Strategic Investment Plan (SDIP 2). Kampala: Ministry of Gender, Labour and Social Development.

MGLSD. 2012a. Poverty, Vulnerability, and Inequality in Uganda. Kampala: Expanding Social Protection Programme, Ministry of Gender, Labour and Social Development.

MGLSD. 2012b. Social Assistance Grant for Empowerment (SAGE) Implementation Guidelines. Kampala: Expanding Social Protection Programme, Ministry of Gender, Labour and Social Development.

MGLSD. 2013. National Social Protection Policy Framework for Uganda: Enabling all Citizens to Participate in and Benefit from Uganda's Social and Economic Transformation (Draft 3). Kampala: Expanding Social Protection Programme, Ministry of Gender, Labour and Social Development).

Mosley, P. 2012. The politics of poverty reduction. Oxford: Oxford University Press.

Msalangi, H.K.M. 1998. Origins of social security in developing countries: the case of African countries. African Journal of Finance and Management, 7(1): 6168.

Mugambe, K. 2011. The Poverty Eradication Action Plan. In Kuteesa, F., Tumusiime-Mutebile, E., Whitworth, A. \& T. Williamson (eds.) Uganda's Economic Reforms: Insider Accounts. Oxford: Oxford University Press, pp. 157171. 
Mugerwa, Y. 2013. Shelved health insurance plan gets new lease of life. Daily Monitor, 20 July. Available at:

http://www.monitor.co.ug/News/National/Shelved-health-insurance-plan-getsnew/-/688334/1920238/-/7wypnrz/-/index.html

NADC. 2012. Mainstreaming disability in the new development paradigm: Evaluation of Norwegian support to promote the rights of persons with disabilities. Uganda country report. Oslo: Norwegian Agency for Development Cooperation.

Nabyonga, J., Desmet, M., Karamagi, H., Kadama, P.Y., Omaswa, F.G. \& O. Walker. 2005. Abolition of cost-sharing is pro-poor: evidence from Uganda. Health Policy and Planning, 20(2): 100-108.

Namuddu, J., Barrett, S., Wandera, A., Okillan, B. \& S. Kasaija. 2014. Evidence on Graduation in Uganda's Social Assistance Grants for Empowerment (SAGE) Scheme and the Feasibility of Promoting Sustainable Livelihoods for Labour Constrained Households Through a Linkages Approach. Brighton: Institute for Development Studies. Available at:

https://www.ids.ac.uk/files/dmfile/Graduationconferencepaper-

Namudduetal.pdf.

Namutebi, J. 2014. Donors give more money for elderly. The New Vision, December 23: 7 .

Nishimura, M., Yamano, T. \& Y. Sasaoka. 2008. Impacts of the universal primary education policy on educational attainment and private costs in rural Uganda. International Journal of Educational Development, 28(2): 161-175.

NRM. 2010. Manifesto 2011-2016. Kampala: National Resistance Movement.

Okillan, B. 2014. Supporting older people and their families to contribute to and benefit from Uganda's social and economic transformation: Updates, Status \& Rollout of the SAGE Senior Citizen Grant scheme. Presentation at launch of Parliamentary Forum on Social Protection, Kampala, Uganda, 4 February.

Onapa, P. 2010. Championing Policy Engagement on Chronic Poverty and Social Protection in Uganda: Experiences from Development Research and Training (DRT). Paper delivered during the conference Ten Years of War Against Poverty. What have we learned since 2000 and what should we do 2010-2020? Manchester: University of Manchester, 8-10 September. 
OPM. 2010. Northern Uganda Social Action Fund II (NUSAF II). Kampala: Office of the Prime Minister. Available at:

http://opm.go.ug/projects/northern-uganda-social-action-fund-ii-nusaf-ii1.html

[Retrieved 2 November 2014].

OPM, EPRC \& S. Neema. 2013. Evaluation of the Uganda Social Assistance

Grants for Empowerment (SAGE) Programme: Baseline report. Oxford: Oxford Policy Management, Economic Policy Research Centre (University of

Makerere) and Department of Anthropology and Sociology (University of

Makerere). Available at:

http://www.opml.co.uk/sites/default/files/OPM_Uganda\%20Report_web_FINA

$\underline{\text { L.pdf }}$

Orem, J.N., Mugisha, F., Kirunga, C. Macq, J. \& B. Criel. 2011. Abolition of user fees: the Uganda paradox. Health Policy and Planning, 26(suppl. 2), pp. ii41-ii51.

Platform for Labour Action. 2008. The Quest for a Transparent and Accountable Social Security System in Uganda. Kampala: Fountain Publishers.

Rakner, L. \& S.E. Helle. 2013. Electoral Mobilization in Uganda and Zambia for the 2011 Elections: The Interplay between Opposition Weakness, Incumbent Strength and the Urban/Rural Electoral Divide. Available at: http://ssrn.com/abstract=2253610

Reinikka, R. 2001. Recovery in Service Delivery: Evidence from Schools and Health Centers. In Reinikka, R. \& P. Collier. (eds.) Uganda's Recovery: The Role of Farms, Firms and Government. Washington, D.C.: World Bank, pp. 343-370.

Robichaud, V., Tiberti, L. \& H. Maisonnave. 2014. Impact of increased public education spending on growth and poverty in Uganda. An integrated micro-macro approach. PEP-MPIA Working Paper 2014-01. PEP-MPIA. Available at: http://ideas.repec.org/p/lvl/mpiacr/2014-01.html

Seekings, J. 201). The Politics of Social Policy in Africa. In Cheeseman, N., Anderson, D. \& A. Scheibler (eds.) Routledge Handbook of African Politics. London: Routledge, pp. 309-321.

Ssewakiryanga, R. Undated. Poverty Reduction in Uganda: Myth or Reality? In Zehn Jahre strategische Armutsbekämpfung - eine Zwischenbilanz, pp. 9-22. Bonn: Verband Entwicklungspolitik deutscher Nichtregierungsorganisationen e. V. (VENRO). Available at: http://www.deinestimmegegenarmut.de/fileadmin/BILDER/doc/Broschueren_2015/2015_im_Ges praech_Nr._15.pdf 
Stasavage, D. 2005. The role of democracy in Uganda's move to universal primary education. Journal of Modern African Studies, 43(1): 53-73.

Synovate. 2011. Knowledge, Attitudes and Practices of Social Protection, Poverty and Vulnerability. (Expanding Social Protection Public Attitude and Communication Survey). Kampala: Synovate Limited.

UBoS. 2010. Uganda National Household Survey 2009/2010. Kampala: Uganda Bureau of Statistics. Available at:

http://www.ubos.org/UNHS0910/unhs200910.pdf

UBoS. 2013. Uganda National Household Survey 2012/2013. Kampala: Uganda Bureau of Statistics. Available at:

http://www.ubos.org/onlinefiles/uploads/ubos/UNHS_12_13/2012_13\%20UNH $\underline{\text { S\%20Final\%20Report.pdf }}$

UN. 2008. Guide to the National implementation of the Madrid International Plan of Action on Ageing. New York: United Nations, Department of Economic and Social Affairs. Available at:

http://www.un.org/esa/socdev/ageing/documents/papers/guide.pdf

UPC. 2010. Manifesto 2011: Programme for the Rehabilitation, Reconstruction and Modernisation of a Failed State. Kampala: Uganda People's Congress. Available at: http://www.upcparty.org/images/upc_manifesto.pdf

Whitworth, A. \& T. Williamson. 2011. Overview of Ugandan Economic Reform since 1986. In Kuteesa, F., Tumusiime-Mutebile, E., Whitworth, A. \& T. Williamson (eds.) Uganda's Economic Reforms: Insider Accounts. Oxford: Oxford University Press, pp. 1-34.

World Bank. 2012. Managing Risk, Promoting Growth: Developing Systems for Social Protection in Africa (The World Bank's Africa Social Protection Strategy 2012-2022). Washington, D.C.: World Bank. Available at: http://siteresources.worldbank.org/INTAFRICA/Resources/social-protectionfull-report-EN-2012.pdf

World Bank. 2014. World Bank Open Data [Data repository]. http://data.worldbank.org

Wylde, E., Sewanyana, S., Ogen, Z. \& A. Kinconco. 2012. Poverty, vulnerability and inequality in Uganda. Kampala: Expanding Social Protection Programme, Ministry of Gender, Labour and Social Development. 
Zimmerman, J.M. \& K. Bohling. 2013. Electronic Payments with Limited Infrastructure: Uganda's Search for a Viable E-payments Solution for the Social Assistance Grants for Empowerment. Washington, D.C.: CGAP and World Bank. Available at: http://www.cgap.org/sites/default/files/eG2P_Uganda.pdf 